Paleozoic-Mesozoic boundary in the Berry Creek quadrangle, northwestern Sierra Nevada, California

GEOLOGICAL SURVEY PROFESSIONAL PAPER 1027

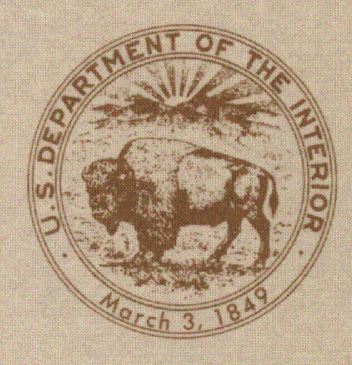

\footnotetext{
CALIFORNIA INSTITUTE OF
TECHNOLOGY

JAN $4 \quad 1978$

U.S. GOVERMMENT OEPOSTIORY
} 



\section{Paleozoic-Mesozoic boundary in the Berry Creek quadrangle, northwestern Sierra Nevada, California}

By Anna Hietanen

GEOLOGICAL SURVEY PROFESIONAL PAPER 1027

Petrologic and structural study

of metamorphic rocks

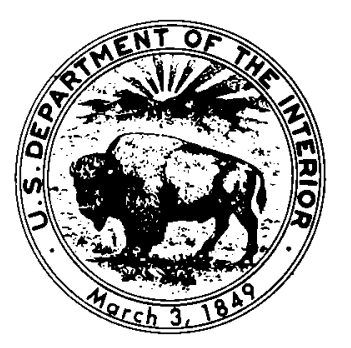




\section{UNITED STATES DEPARTMENT OF THE INTERIOR}

CECIL D. ANDRUS, Secretary

\section{GEOLOGICAL SURVEY}

V. E. McKelvey, Director

Hietanen, Anna Martta, 1909.

Paleozoic-Mesozoic boundary in the Berry Creek quadrangle, northwestern Sierra Nevada, California

(Geological Survey Professional Paper 1027)

Bibliography: p. 22

Includes index.

1. Geology, Stratigraphic--Triassic. 2. Geology, Stratigraphic--Permian. 3. Rocks, Metamorphic.

4. Petrology--California--Butte Co. 5. Geology--California--Butte Co. I. Title: Paleozoic-Mesozoic

Boundary in the Berry Creek quadrangle. II. Series: United States. Geological Survey. Professional paper 1027.

QE676.H53

$551.7 ’ 56 ’ 097944$

$77-608188$

For sale by the Supcrintendent of Documents, U.S. Government Printing Office

Washington, D.C. 20402

Stock Number 024-001-03009-8 


\section{CONTENTS}

\begin{tabular}{|c|c|c|}
\hline & Page & \\
\hline 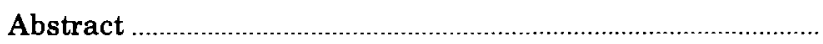 & 1 & Mesozoic Bloomer Hill Formation-Continued \\
\hline Introduction & 1 & Metasodarhyolite \\
\hline Paleozoic metamorphic rocks .. & 2 & Metatuff and tuffaceous metasedimentary rocks ... \\
\hline Distribution and correlation. & 2 & Metamorphosed intrusive rocks \\
\hline Horseshoe Bend Formation & 3 & Ultramafic rooks. \\
\hline Metabasalt & 3 & Metagabbro and metadiorite ............ \\
\hline Basaltic meta-andesite & 5 & Differences between the Paleozoic and \\
\hline Metarhyolite and metadacite. & 5 & Mesozoic metamorphic rocks ......... \\
\hline Metatuff & 6 & Primary structures \\
\hline Hornblende gneiss & 6 & Structures due to deformation \\
\hline Phyllite & 6 & Metamorphism .......................... \\
\hline 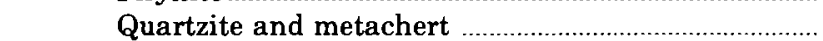 & 7 & 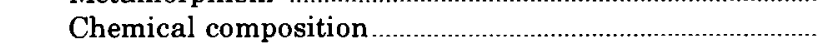 \\
\hline Marble & 7 & Trace elements .................. \\
\hline Phyllite unit south of the Big Bend fault & 7 & Altered plutonic rocks.. \\
\hline Mesozoic Bloomer Hill Formation. & 8 & Altered gabbro \\
\hline Definition and age & 8 & Altered trondhjemite \\
\hline Nature of the basal contact & 8 & Plutonic rocks \\
\hline Metabasalt & 9 & Merrimac pluton \\
\hline Augite basalt & 9 & Bald Rock pluton \\
\hline Metabasalt with plagioclase phenocrysts & 9 & Lovejoy Basalt ................ \\
\hline Meta-andesite & 10 & Conclusions ................... \\
\hline 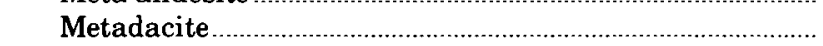 & 11 & References ........ \\
\hline
\end{tabular}

\section{ILLUSTRATIONS}

Plate 1. Geologic map of the Berry Creek quadrangle, Butte County, California

FigURE 1. Index map of northern California showing location of areas studied

2. Photograph showing andesitic metatuff on east side of Dark Canyon ….................................................................... 10

3. Sketch showing outlines of relict shards in metatuff of the Bloomer Hill Formation.................................................... 10

4. Photograph showing pyroclastic structures in meta-andesite at Bloomer Hill Lookout .................................................. 11

5. Photograph showing matrix and subangular to round fragments in pyroclastic metadacite …................................. 12

6. Sketch showing relict outlines of former vesicles in pyroclastic metadacite

7. Sketches of elongate metabasalt fragments in agglomerate of the Bloomer Hill Formation ....................................... 14

8. Ternary diagrams showing variation in composition of metavolcanic rocks of the Berry Creek quadrangle .............. 18

9. Photograph showing cut surface of tonalite from the southwestern part of the Merrimac pluton .............................. 19

10. Ternary diagram showing the normative feldspar content in the monzotonalite of the Merrimac pluton and the trend lines for the neighboring plutons

\section{TABLES}

TABLE 1. Chemical composition in weight and ionic percentages, molecular norms, and trace elements of metavolcanic rocks 



\title{
PALEOZOIC-MESOZOIC BOUNDARY IN THE BERRY CREEK QUADRANGLE, NORTHWESTERN SIERRA NEVADA, CALIFORNIA
}

\author{
By ANia HietaNeN
}

\begin{abstract}
ABSTRAC:I
Structural and petrologic studies in the Berry Creek quadrangle at the north end of the western metamorphic belt of the Sierra Nevada have yielded new information that helps in distinguishing between the chemically similar Paleozoic and Mesozoic rocks. The distinguishing features are structural and textural and result from different degrees of deformation. Most Paleozoic rocks are strongly deformed and thoroughly recrystallized. Phenocrysts in metavolcanic rocks are granulated and drawn out into lenses that have sutured outlines. In contrast, the phenocrysts in the Mesozoic metavolcanic rocks show well-preserved straight crystal faces, are only slightly or not at all granulated, and contain fewer mineral inclusions than do those in the Paleozoic rocks. The groundmass in the Paleozoic rocks is recrystallized to a fairly coarse grained albite-epidote-amphibole-chlorite rock, whereas in the Mesozoic rocks the groundmass is a very fine grained feltlike mesh with only spotty occurrence of well-recrystallized finegrained albite-epidote-chlorite-actinolite rock. Primary minerals, such as augite, are locally preserved in the Mesozoic rocks but are altered to a mixture of amphibole, chlorite, and epidote in the Paleozoic rocks. In the contact aureoles of the plutons, and within the Big Bend fault zone, which crosses the area parallel to the structural trends, all rocks are thoroughly recrystallized and strongly deformed. Identification of the Paleozoic and Mesozoic rocks in these parts of the area was based on the continuity of the rock units in the field and on gradual changes in microscopic textures toward the plutons.
\end{abstract}

\section{INTRODUCTION}

Petrologic and structural studies at the north end of the western metamorphic belt of the Sierra Nevada yield new information concerning the nature of differences between the Paleozoic and Mesozoic rocks and help to place their boundaries more accurately than has been possible previously. Certain differences were found in the textures and structures between chemically and mineralogically similar Paleozoic and Mesozoic metavolcanic units.

The study area is the $7 \frac{1}{2}$-minute Berry Creek quadrangle (fig. 1). It is joined on the north by the western part of the 15-minute Pulga quadrangle (Hietanen, 1973a), on the west by the 15-minute Oroville quadrangle (Creely, 1965), and on the east by the $7 \frac{1}{2}$-minute Brush Creek quadrangle (Hietanen, 1976). The northeastern part of the study area is underlain by the southwestern part of the Merri- mac pluton (Hietanen, 1951). The southeastern part is underlain by a part of the Bald Rock pluton; the southern extension of this pluton southeast of Berry Creek was described by Compton (1955).

The Big Bend fault zone, which extends from the northwest corner of the study area to the east-central part and farther to the east through the metamorphic rocks between the Merrimac and Bald Rock plutons, divides the study area into two parts. The metamorphic rocks north of this fault envelop the Merrimac pluton and are continuous with the Horseshoe Bend Formation in the Pulga quadrangle (Hietanen, 1973a) to the north. Two petrologically and structurally different units are exposed south of the fault: an older phyllite unit in the west central part and younger metavolcanic rocks, named the Bloomer Hill Formation in this report, in the southern part. The phyllite unit is an eastern extension of Creely's (1965) "undifferentiated Calaveras Formation" in the Oroville quadrangle (fig. 1) and is structurally its uppermost unit. The Bloomer Hill Formation is exposed at higher elevations above the phyllite and has thus a stratigraphic position similar to that of Creely's (1965) Oregon City Formation of Late Jurassic age in the Oroville quadrangle. In the limestone interbedded with the rocks of the Calaveras Formation, Creely (1965) found Permian(?) tetracorals and an ammonite of probable Late Triassic age in the overlying Mesozoic metavolcanic rocks. On the Chico sheet of the Geologic Map of California (Burnett and Jennings, 1962), the phyllite is shown as Paleozoic marine.

The Horseshoe Bend Formation was tentatively correlated by Hietanen (1973a, 1976) on a lithologic basis with the Permian formations in the Taylorsville area (McMath, 1966) and with the interbedded metasedimentary and metavolcanic rocks of the western Paleozoic and Triassic belt of the Klamath Mountains (Irwin, 1966, 1972). The metasedimentary rocks within the Big Bend fault zone are similar to those exposed north of it and are therefore considered parts of the same (Horseshoe Bend) forma- 


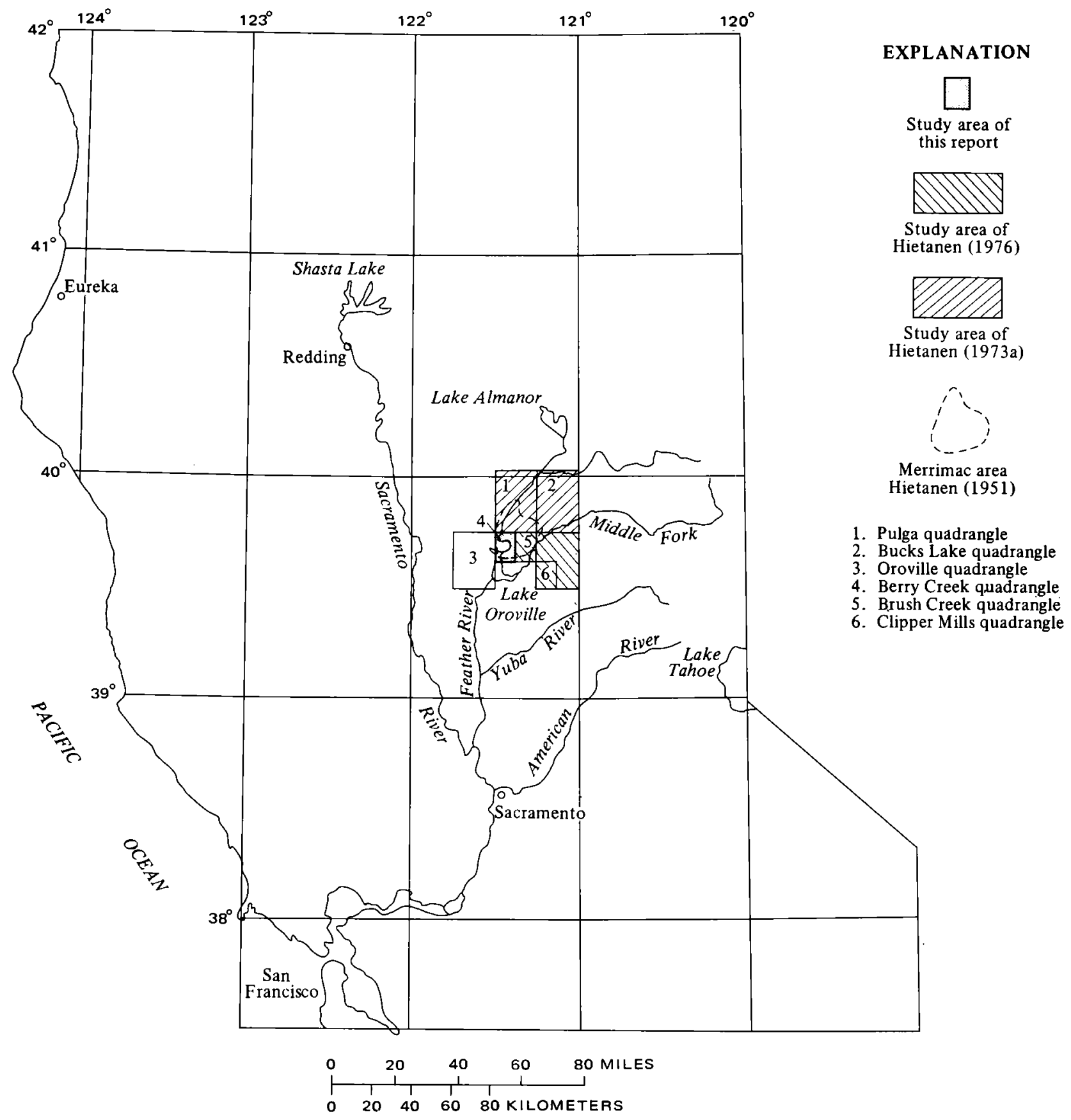

FIGURE 1.-Index map of northern California showing location of areas studied.

tion. Comparison of the structural relations along the fault zone in the study area and along its southeastern extension in the Clipper Mills quadrangle supports this correlation. In the Clipper Mills quadrangle (fig. 1) (Hietanen, 1976), the various en echelon branches of the Big Bend fault-each accompanied by thin long bodies of ultramafic rockshave extensively sliced the rocks of the Horseshoe Bend Formation, and the Mesozoic metavolcanic rocks are west of the westernmost branch. In the
Berry Creek quadrangle the Big Bend fault zone includes three major faults, each accompanied by ultramafic rocks (pl. 1, cross section $A-A^{\prime}$ ). The Bloomer Hill Formation crops out south of the southernmost branch representing the north end of the Mesozoic belt.

\section{PALEOZOIC METAMORPHIC ROCKS DISTRIBUTION AND CORRELATION}

The Paleozoic metamorphic rocks are divided into 
two major belts by the Big Bend fault zone which passes through the northern part of the quadrangle (pl. 1). The belt north of the fault zone includes mainly metavolcanic rocks with subordinate amounts of metasedimentary rocks, phyllite and quartzite. In contrast, phyllite makes up most of the belt south of the fault zone, the layers of metavolcanic rocks being minor.

Metabasalt and metatuff form the major part of the northern belt. Each of these rock types occurs as discontinuous layers, $100-800 \mathrm{~m}$ thick and several kilometers long, parallel to the regional trends. A few small occurrences of metarhyolite are in the eastcentral part of the quadrangle. Several long layers of phyllite and quartzite, $10-300 \mathrm{~m}$ thick, are interbedded with metavolcanic rocks. A layer of marble is exposed along the North Fork of the Feather River at the old Poe railroad station.

Phyllite is the major rock type in the west-central part of the quadrangle, south of the Big Bend fault zone. Interbedded with the phyllite are a few discontinuous layers of quartzite, lithic metagraywacke, and metatuff. These rocks are excellently exposed along the Dark Canyon Road, the old Feather River highway, that traverses the west margin of the Berry Creek quadrangle. Metatuff, quartzite, and phyllite make up most of the Paleozoic rocks on the Stephens Ridge, northwest of the Bald Rock pluton (pl. 1).

The northern belt is continuous with the Horseshoe Bend Formation named by Hietanen (1973a) for exposures in the Pulga and Bucks Lakes quadrangles. The "unnamed metavolcanic rocks" of Creely (1965) in the northeast corner of the Oroville quadrangle are a western extension of one of the metavolcanic units in the Horseshoe Bend Formation.

The western extension of the phyllite unit south of the Big Bend fault zone was mapped by Creely (1965) as "undifferentiated Calaveras Formation" and considered Permian(?) in age. According to Creely, the major part of these Permian(?) rocks consist of a thick succession of interbedded phyllite, sandstone, and metavolcanic rocks with minor metachert and limestone. In lithology they resemble the Horseshoe Bend Formation, particularly its upper part as exposed north of the North Yuba River (Hietanen, 1976). Layers of lithic metagraywacke, not common elsewhere, are typical of this uppermost unit. The phyllite unit in the Berry Creek quadrangle includes thin, discontinuous units of metachert, metagraywacke, and metatuff.

The Paleozoic metasedimentary rocks on Stephens Ridge are lithologically similar to the Horseshoe
Bend Formation. Their structural position is similar to that of the phyllite unit in the western part of the quadrangle. On Stephens Ridge these rocks are south of the Big Bend fault zone and are overlain by Mesozoic metavolcanic rocks in the west. A fault at the contact is not ruled out. A narrow strip of the Permian(?) rocks continues southward enveloping the west side of the Bald Rock pluton.

\section{HORSESHOE BEND FORMATION}

$$
\text { METABASAL T }
$$

About half of the metavolcanic rocks within and north of the Big Bend fault zone consists of darkgreenish-gray to black metabasalt. Massive layers, originally thick flows, are interbedded with strongly schistose layers. Most of the metabasalt in a $2-\mathrm{km}$ wide contact aureole of the Merrimac pluton is recrystallized to well-foliated amphibolite in which black hornblende needles can be identified in the field.

Thin sections show that the dark-gray metabasalt consists mainly of green hornblende (40-60 percent), plagioclase $\mathrm{An}_{\overline{5}-15}$ (20-35 percent), and epidote (10-30 percent). Ilmenite and magnetite (2-5 percent), some chlorite, quartz, and sphene are commonly present. The scarce amygdules are filled with chlorite and quartz.

Hornblende is optically similar to the green variety common in the inner contact aureoles of the plutons in the Bucks Lake quadrangle (Hietanen, 1973a, 1974) and is presumably also chemically alike. It is pleochroic in blue green to pale green and has $\gamma=$ 1.67-1.69. Near the plutons hornblende needles are subparallel to the lineation, but elsewhere they are subparallel to the plane of foliation and lie at random on this plane.

Albitic plagioclase in fine-grained metabasalt and in the groundmass of a porphyritic variety is in interstitial small grains. Albite also occurs as a few large subhedral phenocrysts and scattered clusters of small grains. Crystal boundaries of the relict phenocrysts are sutured and traversed by hornblende needles. The clusters of small grains are drawn out parallel to the foliation and include granulated quartz and hornblende needles.

Epidote is in small scattered anhedral grains or in clusters next to and within the hornblende prisms, or more rarely as inclusions in albite. Magnetite is in euhedral crystals in the well-recrystallized amphibolite near the plutons; elsewhere it forms numerous tiny grains that are elongate parallel to the foliation or segregated along surfaces that mark relict fragments in a brecciated flow or tuff. 
TABLE 1.-Chemical composition in weight and ionic percentages, molecular norms, and trace elements of metavolcanic rocks [Chemical analyses in weight percent by Edythe Engleman; spectrographic analyses by Chris Heropoulos]

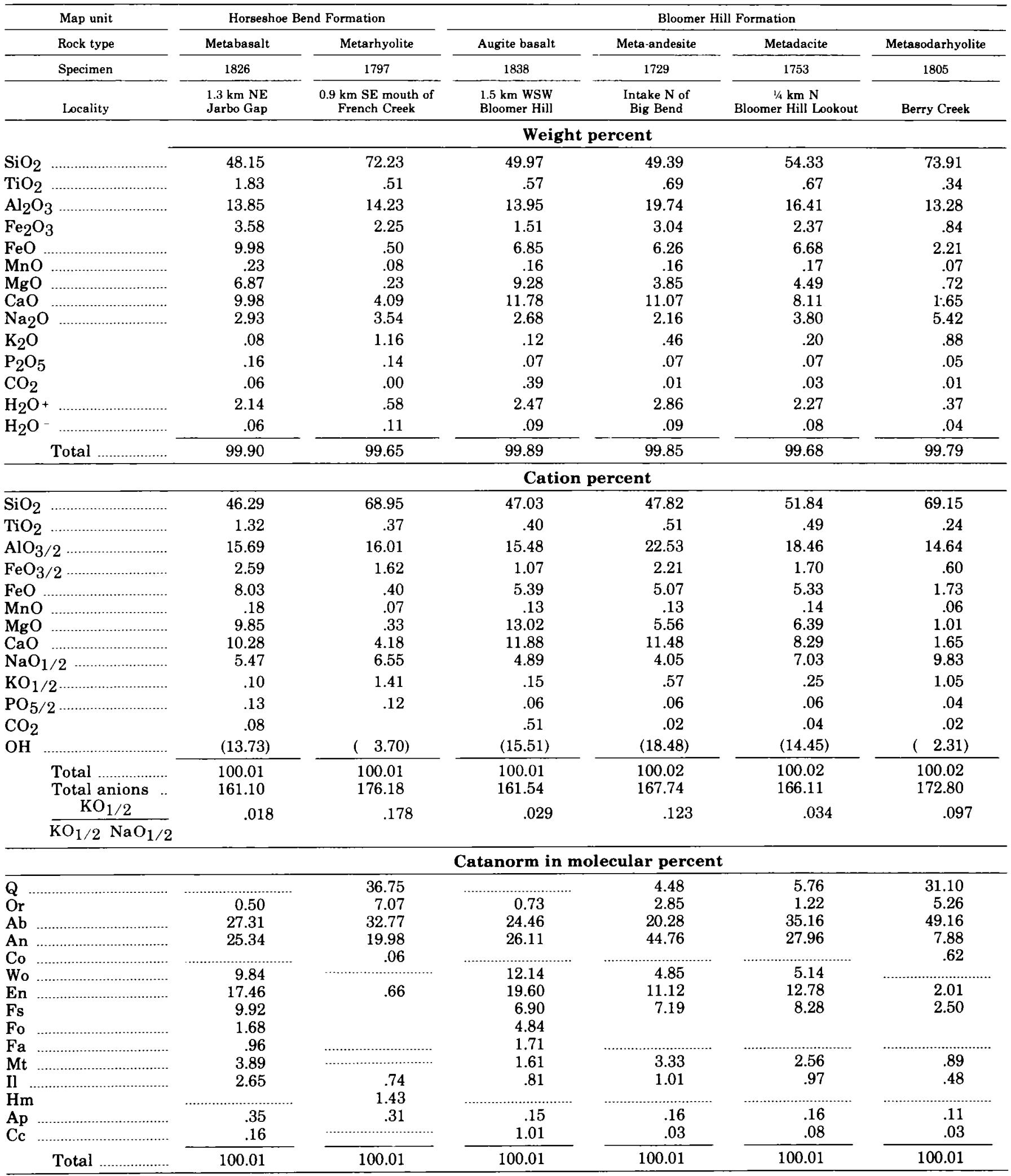


TABLE 1.-Chemical composition in weight and ionic percentages, molecular norms, and trace elements of metavolcanic rocks-Cont.

\begin{tabular}{|c|c|c|c|c|c|c|}
\hline \multirow{2}{*}{$\begin{array}{l}\text { Map unit } \\
\text { Rock type }\end{array}$} & \multicolumn{2}{|c|}{ Horseshoe Bend Formation } & \multicolumn{4}{|c|}{ Bloomer Hill Formation } \\
\hline & Metabasalt & Metarhyolite & Augite basalt & Meta-andesite & Metadacite & Metasodarhyolite \\
\hline Specimen & 1826 & 1797 & 1838 & 1729 & 1753 & 1805 \\
\hline \multirow[t]{2}{*}{ Locality } & $\begin{array}{l}1.3 \mathrm{~km} \mathrm{NE} \\
\text { Jarbo Gap }\end{array}$ & $\begin{array}{l}0.9 \mathrm{~km} \text { SE mouth of } \\
\text { French Creek }\end{array}$ & $\begin{array}{l}1.5 \mathrm{~km} \text { WSW } \\
\text { Bloomer Hill }\end{array}$ & $\begin{array}{l}\text { Intake } N \text { of } \\
\text { Big Bend }\end{array}$ & $\begin{array}{l}1 / 1 / \mathrm{km} \mathrm{N} \\
\text { Bloomer Hill Lookout }\end{array}$ & Berry Creek \\
\hline & \multicolumn{6}{|c|}{ Epinorm in molecular percent } \\
\hline Quartz & 1.66 & 38.85 & $(-.34)$ & 10.80 & 10.19 & 32.64 \\
\hline Orthoclase & .50 & 1.94 & .73 & .75 & 1.22 & 1.76 \\
\hline Albite ............ & 27.31 & 32.77 & 24.46 & 20.28 & 35.16 & 49.16 \\
\hline Muscovite & & 7.19 & & 2.95 & & 4.90 \\
\hline $\begin{array}{l}\text { Zoisite } \\
\text { Actinolite }\end{array}$ & $\begin{array}{l}27.03 \\
24.22\end{array}$ & 15.98 & $\begin{array}{l}27.85 \\
32.45\end{array}$ & 45.51 & $\begin{array}{r}29.82 \\
5.29\end{array}$ & 6.31 \\
\hline $\begin{array}{l}\text { Actinolite } \\
\text { Antigorite }\end{array}$ & $\begin{array}{l}24.22 \\
12.28\end{array}$ & .55 & $\begin{array}{l}32.45 \\
11.32\end{array}$ & 15.25 & $\begin{array}{r}5.29 \\
14.61\end{array}$ & 3.76 \\
\hline $\begin{array}{l}\text { Magnetite } \\
\text { Hematite }\end{array}$ & 3.89 & $\begin{array}{r}.30 \\
1.43\end{array}$ & 1.61 & 3.33 & 2.56 & .89 \\
\hline Ilmenite & 2.65 & .74 & .81 & 1.01 & .97 & .48 \\
\hline Apatite & .35 & .31 & .15 & .16 & .16 & .11 \\
\hline Calcite & .16 & & 1.01 & .03 & .08 & .03 \\
\hline \multirow[t]{2}{*}{ Total } & 100.00 & 100.00 & 100.34 & 100.00 & 100.00 & 100.00 \\
\hline & \multicolumn{6}{|c|}{ Trace elements in parts per million } \\
\hline $\mathrm{Ba} \ldots \ldots$ & 17 & 230 & 68 & 110 & 96 & 230 \\
\hline Co & 53 & 12 & 48 & 35 & 34 & 6 \\
\hline $\mathrm{Cr}$ & 96 & & 300 & 21 & 29 & \\
\hline $\mathrm{Cu}$ & 320 & 6 & 320 & 50 & 120 & 10 \\
\hline $\mathrm{Ni}$ & 58 & & 95 & 11 & 21 & \\
\hline $\mathrm{Sc}$ & 52 & 20 & 50 & 44 & 44 & 15 \\
\hline $\mathrm{Sr}$. & 130 & 150 & 185 & 260 & 170 & 62 \\
\hline V & 410 & 16 & 320 & 290 & 330 & 32 \\
\hline $\mathrm{Y}$ & 62 & 48 & 27 & 29 & 25 & 44 \\
\hline $\mathbf{Z r}$ & 150 & 160 & 65 & 77 & 62 & 180 \\
\hline $\mathrm{Ga}$ & 21 & 17 & 15 & 21 & 17 & 15 \\
\hline $\mathrm{Yb}$ & 4 & 4 & 2.5 & 3 & 2.5 & 3 \\
\hline
\end{tabular}

Chemical analysis of metabasalt $1.3 \mathrm{~km}$ northeast of Jarbo Gap (table 1, specimen 1826) shows that the composition of this rock is similar to that of the metabasalt of the Horseshoe Bend Formation in the Bucks Lake quadrangle (Hietanen, 1973a, table 1, specimen 551) except for a little less silicon and sodium and more calcium and magnesium.

\section{BASALTIC: META-ANDESIIE}

Two elongate masses within the Big Bend fault zone, shown as basaltic meta-andesite on the geologic map (pl. 1) are rather inhomogeneous and grade in places into genetically related rock types such as metadiorite and metagabbro, or more rarely into metadacite and metabasalt. Moreover, much of the rock east of Jarbo Gap is tuff breccia in which fragments of metabasalt, metadacite, metadiorite, and metagabbro occur along with those consisting of meta-andesite.

The main part of the masses consists of lightgreenish-gray medium-grained rock composed of about 50 percent epidote, $30-35$ percent albite, 10-15 percent pale-green amphibole, and 5 percent chlorite.
Sphene and leucoxene occur as accessory minerals. With an increase in the percentage of hornblende and decrease in the percentage of epidote, metaandesite grades into metabasalt near Intake and west of the mouth of French Creek.

In the tuff breccia the individual fragments range from $1 / 2 \mathrm{~mm}$ to several centimeters in size and from subangular to round in shape. Metadiorite and metagabbro in the fragments have a subophitic texture similar to that in the adjacent metadiorite. Plagioclase in these rocks is in stocky laths, whereas amphibole is interstitial. The matrix is rich in epidote and contains light-green amphibole, albite, chlorite, and sphene.

\section{METARHYOLITE AND METADACITE}

Only a few small occurrences of metarhyolite are interlayered with the metabasalt and metatuff. This rock is light greenish gray to very light gray and consists of quartz, albite, epidote, muscovite, and biotite with or without chlorite. Small prisms of hornblende are common in some layers. The accessory minerals are magnetite, sphene, leucoxene, and apa- 
tite. Most of the phenocrysts of quartz and albite are granulated and deformed into lens-shaped clusters with irregular boundaries. Large grains of epidote are included in these clusters, and small grains of epidote are scattered in the granoblastic groundmass that consists of small grains of quartz, albite, and some biotite or chlorite. Muscovite is in large stubby flakes or large rounded grains that include many round grains of quartz and some small grains of epidote. The shape of these muscovite poikiloblasts suggests that they were originally orthoclase phenocrysts. In some layers the groundmass has tiny subparallel laths of albite indicating relict flow structure.

Chemical analysis of metarhyolite from $0.9 \mathrm{~km}$ southeast of the mouth of French Creek (table 1, specimen 1797) shows that this rock has a high silica and very low magnesium content. It has more potassium and less calcium than the Paleozoic metasodarhyolite in the Bucks Lake quadrangle (Hietanen, 1973a, table 1, specimen 461).

With an increase in the percentage of hornblende and epidote and a decrease in the percentage of quartz and muscovite, the metarhyolite grades into medium-greenish-gray metadacite. Phenocrysts of albite in the metadacite are in stubby laths that have sutured boundaries and enclose subhedral grains of epidote. The groundmass contains small laths of albite with sutured boundaries. Most of the epidote is in clusters that tend to be elongate parallel to the lineation or foliation but have irregular outlines. Hornblende is pleochroic in bluish green to pale green.

\section{METATUFF}

In the north-central part of the quadrangle, the North Fork of the Feather River and the lower drainage of French Creek traverse layers of metatuff that are interbedded with metabasalt. Exposures along the old railroad following the river are excellent, and they show that most of the metatuff is fine grained and distinctly bedded; thin-bedded strata, in which layers are 1-4 cm thick, alternate with thicker (10-20 $\mathrm{cm}$ ) homogeneous layers. Most of these layers consist of dark-gray to black rock rich in hornblende, but some greenish-gray layers rich in epidote and some light-gray layers that contain a considerable amount of quartz and plagioclase are interbedded.

In the northwest corner of the quadrangle many layers, several meters thick, consist of hornblende and epidote in equal amounts and contain only a few grains of plagioclase $\left(\mathrm{An}_{10}\right)$ and pods of small grains of quartz. Calcite fills cracks and forms thin, strongly folded, discontinuous laminae that are transected by cleavage. These laminae probably are parallel to a folded bedding.

Most of the metatuff is basaltic in composition; various layers consist of 40-60 percent hornblende, 10-40 percent epidote, $10-50$ percent plagioclase, and some quartz, chlorite, muscovite, sphene, leucoxene, magnetite, pyrite, pyrrhotite, and rarely apatite. With an increase in the percentage of albite and quartz and a decrease in that of hornblende, the composition of the metatuff becomes dacitic, rarely rhyolitic.

In metatuff near the plutons, hornblende is in bluish-green prisms subparallel to the lineation; elsewhere it is subparallel to the plane of foliation. Epidote is in small subhedral to anhedral scattered grains among the hornblende crystals and clustered with the plagioclase. Muscovite, where present, is included in or is next to plagioclase. Lens-shaped aggregates consisting of tiny polygonal grains of quartz are embedded in some hornblende-rich layers. These aggregates were probably originally fragments of metachert or quartz sand; they are more numerous in layers next to metasedimentary rocks.

\section{HORNBLENDE CNEISS}

A discontinuous thin body of medium-grained light-gray foliated hornblende-plagioclase rock along the southernmost branch of the Big Bend fault zone on Stephens Ridge is shown as hornblende gneiss on the geologic map (pl. 1). In its mineralogy and structure this rock resembles the hornblende gneiss exposed locally near the plutons in the Pulga and Bucks Lake quadrangles (Hietanen, 1973a). Variation in grain size and in the percentage of the major constituents, hornblende and plagioclase, lends it a crude layering reminiscent of that in the metatuff. The rock on Stephens Ridge, however, is coarser grained and more homogeneous than the nearby layers of metatuff. Scattered small phenocrysts of plagioclase suggest that it could be a near-surface sill or a dikelike body.

PIIYIIIITE

Only a few rather thin units of phyllite are interbedded with metavolcanic rocks in the northern part of the quadrangle where tuffaceous layers that have been recrystallized to hornblende schist or to hornblende-biotite schist are common. Two long phyllite units along the river southwest of the Merrimac pluton (pl. 1) are thin bedded and contain some layers rich in quartz and others rich in hornblende.

Thin sections show that phyllite consists mainly of muscovite, chlorite, and quartz. Biotite has re- 
placed most of the chlorite near the plutons. Disseminated carbonaceous material is particularly plentiful along some thin laminae. Hornblendebearing layers consist of green to light-green hornblende, quartz, albite, and epidote with or without biotite. Their mineralogy together with the occurrence of some euhedral albite phenocrysts indicates that these layers contain tuffaceous material. A thin section made of a light-gray very fine grained layer interbedded with phyllite half a kilometer west of the mouth of French Creek (loc. 1824) shows subhedral albite grains and round spherulites of quartz and feldspar in a foliated matrix of muscovite, quartz, and feldspar. This layer was most likely a rhyolitic tuff.

A layer of metagraywacke is interbedded with phyllite at the north end of a railroad bridge near Intake. The fragments are subangular, $0.2-20 \mathrm{~mm}$ long, and consist mainly of quartzite, metachert, phyllite, metarhyolite, metadacite, quartz, and albite. The matrix is chlorite-biotite phyllite colored dark by disseminated iron oxides.

\section{QI'ARTYITE AND MEIACIHER I}

Layers of metachert and quartzite are interbedded with phyllite and metatuff in the northern part of the quadrangle and on Stephens Ridge. Metachert consists of 2- to 8-cm-thick layers of pure dark- to lightgray fine-grained quartzite separated by thin phyllitic layers. With an increase in the grade of metamorphism toward the plutons, the quartz-rich layers grade into light-gray to white granular quartzite and biotite instead of muscovite and chlorite crystallized in the thin phyllitic layers. The regularity of the thickness and contrasting composition of the quartzrich and mica-rich beds of the metachert are thus preserved during the recrystallization and reveal the origin of these quartzite layers.

In contrast, most layers in the quartzite that was deposited as a quartz sand contain muscovite and biotite or chlorite in varying quantities, and the contacts between mica-rich and quartz-rich layers are gradational. Thickness of the beds in this quartzite is more variable than in the metachert. Much of the quartzite $n$ the northern part of the quadrangle belongs to this clastic variety.

Every gradation from a very fine grained metachert to medium-grained granoblastic quartzite can be seen under the microscope. The fine-grained metachert is traversed by numerous veins in which quartz grains are much larger than in the main part of the rock. Pods and wide veins consisting of large quartz grains are common in the advanced stage of recrystallization. At the highest grade next to the plutons, all the quartz is in elongate grains of medium size.

\section{MARBI.E}

A discontinuous layer of marble, $30 \mathrm{~m}$ thick, is exposed at the old Poe railroad station and to the northwest along the North Fork of the Feather River. It is underlain by white granular quartzite in the south and overlain by phyllite in the north. The contact with the phyllite is gradational. The marble is thin bedded; pure white carbonate beds alternate with bluish-gray ones that contain disseminated magnetite. Carbonate in similar occurrences in the neighboring quadrangles is calcite with $\omega=1.491 \pm$ $0.001, \omega=1.652 \pm 0.001$ (Hietanen, 1951, p. 576).

\section{PHYLLITE UNIT SOUTH OF THE BIG BEND FAULT}

A continuous section through the southernmost phyllite unit is exposed along Dark Canyon Road and on the ridge between this canyon and the river on the west border of the quadrangle. The phyllite is distinctly bedded and has a well-developed foliation with a silky sheen. Fresh exposures are dark gray to greenish gray or black owing to disseminated carbonaceous material. Weathered surfaces are brownish gray. A few thin layers of metatuff and tuffaceous metasediment are interbedded. Some pebbly layers and layers of lithic metagraywacke are exposed along Dark Canyon and on the ridge near Las Plumas substation.

Clasts in metagraywacke interbedded with phyllite are subangular to elongate fragments of metachert, phyllite, quartzite, and albite. In fine-grained layers along Dark Canyon, clasts are well sorted with respect to size $(0.1-0.2 \mathrm{~mm})$ but less so near Las Plumas substation where some fragments are $1 \frac{1 / 2}{\mathrm{~cm}}$ long. The matrix in the metagraywacke is phyllitic and consists of muscovite, chlorite, quartz, some biotite, and accessory minerals-magnetite, sphene, and disseminated carbonaceous material.

A strongly folded discontinuous layer of gray thinbedded metachert is interbedded with phyllite in a roadcut west of Parkhill. Boulders from another layer of metachert occur on a ridge southwest of Las Plumas substation. This layer is dark blue gray and in part coarse grained. A layer of thin-bedded granular quartzite, $30 \mathrm{~m}$ thick, is exposed $1 \mathrm{~km}$ south of Parkhill. Phyllite north of it contains pebbles of similar quartzite, and the black phyllite south of it is transected by numerous veins of calcite.

Layers of thin-bedded amphibole-bearing metatuff are common along the North Fork of the Feather 
River southwest of Las Plumas substation. The metatuff consists mainly of amphibole, chlorite, albite, epidote, quartz, and sphene. Some of the metatuff layers in the southwest corner of the quadrangle include strongly deformed meta-andesite and metadacite. Meta-andesite contains aggregates of amphibole and chlorite that have outlines of augite crystals in the $a c$ plane of the rock but that are strongly elongate parallel to the lineation. The groundmass consists of chlorite, small prisms of palegreen amphibole, albite, and epidote. A few amygdules are filled with quartz and chlorite.

\section{MESOZOIC BLOOMER HILL FORMATION DEFINITION AND AGE}

A sequence of metavolcanic rocks ranging in composition from mafic augite basalt through andesite and dacite to sodarhyolite is exposed in the southwestern part of the Berry Creek quadrangle. This sequence is here named the Bloomer Hill Formation after a prominent mountain, Bloomer Hill (sec. 30, T. 21 N., R. 5 E.) where these rocks are well exposed. The stratigraphically lowest unit of the Bloomer Hill Formation in the west-central part of the quadrangle consists of fragmentary meta-andesite, metatuff, metasodarhyolite, and minor metadacite. In the southern part around Bloomer Hill and to the east, the metadacite and metasodarhyolite are the major rock types and are underlain by heterogeneous basal units in the east and in the west.

The type section is a west-southwest section across Bloomer Hill in sec. 30, T. 21 N., R. 5 E. and continuing from there to the southwest along a prominent ridge in secs. 25 and 26, T. 21 N., R. 4 E., and to the east of Bloomer Hill in secs. 29 and 28 , T. 21 N., R. 5 E. This section includes four units: an eastern basal unit, a western basal unit, a metadacite unit, and a metasodarhyolite unit. The western basal unit of the section near the North Fork of the Feather River consists of an interfingering sequence of metasodarhyolite, metadacite, metatuff, basaltic meta-andesite, and augite basalt. This heterogeneous sequence is overlain by a thick unit of metadacite that extends for more than $2 \mathrm{~km}$ over Bloomer Hill. The next unit to the east consists of metasodarhyolite that includes some metadacite, meta-andesite, and metatuff. The eastern basal unit, which is well exposed in roadcuts of the OrovilleQuincy highway southwest of Berry Creek, consists of metabasalt that includes lens-shaped masses of metasodarhyolite and some metadacite. The thicknesses of the units across Bloomer Hill are difficult to estimate because of folding. The metadacite and metasodarhyolite units are probably thicker than the basal units. The metabasalt in the eastern basal unit near Berry Creek could be as much as $700 \mathrm{~m}$ thick and the other units about $1,000 \mathrm{~m}$. In contrast, the northernmost exposures are only about $100 \mathrm{~m}$ thick.

The Bloomer Hill Formation is considered Jurassic in age. It is less thoroughly recrystallized and less deformed than the Paleozoic rocks. The age is based on broad correlation with the Late Jurassic Oregon City Formation of Creely (1965, p. 21-24) on the west side of the North Fork of the Feather River in the adjoining Oroville quadrangle. The stratigraphic position of the Bloomer Hill Formation overlying on the phyllite unit south of the Big Bend fault is similar to the stratigraphic relations between the Oregon City Formation and the Permian(?) to Mississippian(?) metasedimentary rocks described by Creely (1965) in the adjoining Oroville quadrangle. The actual contact is generally covered by talus. In a few localities a fault breccia or a layer of powdered and weathered rock separates the Bloomer Hill Formation from the rocks of the phyllite unit. Since the outcrops of the metasedimentary rocks in these two quadrangles are continuous, it is assumed that the overlying volcanic rocks are also broadly correlative in age. The petrologic similarity of the augite basalt of the Bloomer Hill Formation and parts of the Oregon City Formation of Creely supports this view. According to fossil evidence given by Creely (1965, p. 24), the Oregon City Formation is Late Jurassic and is probably correlative with the Logtown Ridge Formation (Clark, 1964) farther south.

\section{NATURE OF THE BASAL CONTACT}

In the central part of the quadrangle, a fault and long thin bodies of serpentine and metagabbro separate the Mesozoic Bloomer Hill Formation in the south from the Paleozoic rocks in the north. These igneous bodies conceal parts of a discontinuous fault that forms the southern branch of the Big Bend fault zone (pl. 1, cross section $A-A^{\prime}$ ). Two other faults are 1 $2 \mathrm{~km}$ farther north, and the rocks along the wide fault zone are interbedded metasedimentary and metavolcanic rocks typical of the Horseshoe Bend Formation. The contact between the Bloomer Hill and Horseshoe Bend Formations along the river south of the mouth of French Creek was placed along a thin dikelike body of metagabbro because the metatuff just to the south includes subangular, lapilli-size fragments of metabasalt that is similar to the metabasalt of the Bloomer Hill Formation to the south. In contrast, the metatuff along the fault zone north of 
the metagabbro body is well bedded and strongly deformed as is typical of the Horseshoe Bend Formation. Also, potassium-poor metarhyolite east of the Mesozoic lapilli tuff is strongly deformed and is therefore mapped as part of the Horseshoe Bend Formation. This potassium-poor metarhyolite is exposed along a prominent ridge north of Stephens Ridge (loc. 1797). It has a strong $b$ lineation that plunges $45^{\circ}-60^{\circ}$ to the east-northeast, thus under the Mesozoic rocks in the west.

In the western part of the quadrangle and on Stephens Ridge, northwest of the Bald Rock pluton, the nature of the basal contact of the Bloomer Hill Formation is uncertain. In the west-central part of the quadrangle, on either side of Dark Canyon, fragmentary meta-andesite of the Bloomer Hill Formation is exposed at higher elevations above the bedded phyllite, but the actual contact is covered by talus. At one locality on the eastern slope, a layer of weathered rock, probably a fault breccia, 1 to several meters thick, is exposed at the contact. Along the North Fork of the Feather River, $2 \mathrm{~km}$ to the south, the contact is interfingering because of the folding and faulting. Farther south the strongly deformed Paleozoic(?) phyllite and metatuff are exposed low along the river bank, and the rocks of the Bloomer Hill Formation, which are only slightly deformed, are above them at higher elevations.

On the western slope of Stephens Ridge the wellexposed metabasalt of the Bloomer Hill Formation rests unconformably on various layers of the Horseshoe Bend Formation. At one locality, fragments of weathered rock cemented together by a matrix rich in iron oxides mark the contact between these two formations. To the south most of the Paleozoic rocks have been pinched out by the Bald Rock pluton. Near the south border of the quadrangle, correlation becomes uncertain because of strong deformation and thorough recrystallization of all rocks.

\footnotetext{
METABASALT

AI'TIIE. BASAI,I
}

Metabasalt with well-preserved euhedral phenocrysts of augite is exposed in the southwestern part of the quadrangle $1 \frac{1}{1} 2-2 \mathrm{~km}$ west-south west of Bloomer Hill. The groundmass in the metabasalt is recrystallized to a fine-grained mixture of amphibole, albite, epidote, and chlorite. Magnetite, sphene, and leucoxene occur as accessory minerals. Quartz and calcite together with epidote and chlorite fill the amygdules. Small prisms of colorless to pale-green amphibole form a feltlike mesh that includes tiny grains of sphene and leucoxene. Albite is interstitial or in small laths. Epidote occurs as individual grains $0.5-1 \mathrm{~mm}$ long or is clustered with chlorite. Some of these clusters may be alteration products after some ferromagnesian mineral (pyroxene?), and some others are amygdules. Locally augite has altered to chlorite + amphibole, and plagioclase has altered to albite + muscovite + epidote. A part of the augite basalt is mafic; the groundmass consists mainly of hornblende with less albite and epidote. In this rock chlorite fills the amygdules, and there is less epidote than in the common variety. Some of the lapilli tuff interbedded with augite basalt (for example, loc. 1839) is strongly deformed and may have been a welded tuff. This notion is supported by the strongly elongate shape of the bombs in some layers.

Chemical analysis of augite basalt from $1 \frac{1}{2} \mathrm{~km}$ west-southwest of Bloomer Hill (table 1 , specimen 1838) shows that this rock is richer in calcium and magnesium and poorer in iron and titanium than the metabasalt of the Horseshoe Bend Formation (specimen 1826).

\section{METABASALT WITH PLAGIOCLASE PHENOCRYSIS}

The lowest unit of the Bloomer Hill Formation on its east side is within the contact metamorphic aureole of the Bald Rock pluton. This unit is well exposed along the North Fork of the Feather River north of Wild Yankee Hill and in roadcuts of the Oroville-Quincy highway near Berry Creek. The major rock type is black metabasalt with numerous white plagioclase phenocrysts and amygdules consisting of epidote and quartz. Interbedded with the apparent flows are thin-bedded foliated layers of basaltic metatuff.

Thin sections show that the metabasalt is completely recrystallized but only slightly deformed. The phenocrysts of plagioclase $\left(\mathrm{An}_{8-15}\right)$ have euhedral shapes, but they are partly granulated and include small prisms of hornblende and grains of epidote. The groundmass consists of small stubby prisms of bluegreen hornblende, subhedral grains of epidote, interstitial plagioclase, and some magnetite. The amygdules are filled with quartz and epidote. The spherical shape of amygdules is well preserved in outcrops along the river, $1 \frac{1}{2} \mathrm{~km}$ from the Bald Rock pluton. Closer to the pluton the metabasalt is foliated and has a strong lineation parallel to the fold axes.

Layers of basaltic metatuff that are interbedded with metabasalt are strongly foliated, and many are thin bedded. Major constituents are green hornblende, plagioclase, epidote, and quartz. Magnetite is a common accessory mineral. An agglomeratic layer in the metatuff just north of the metabasalt contains angular to rounded fragments, $1-3 \mathrm{~cm}$ long, of 


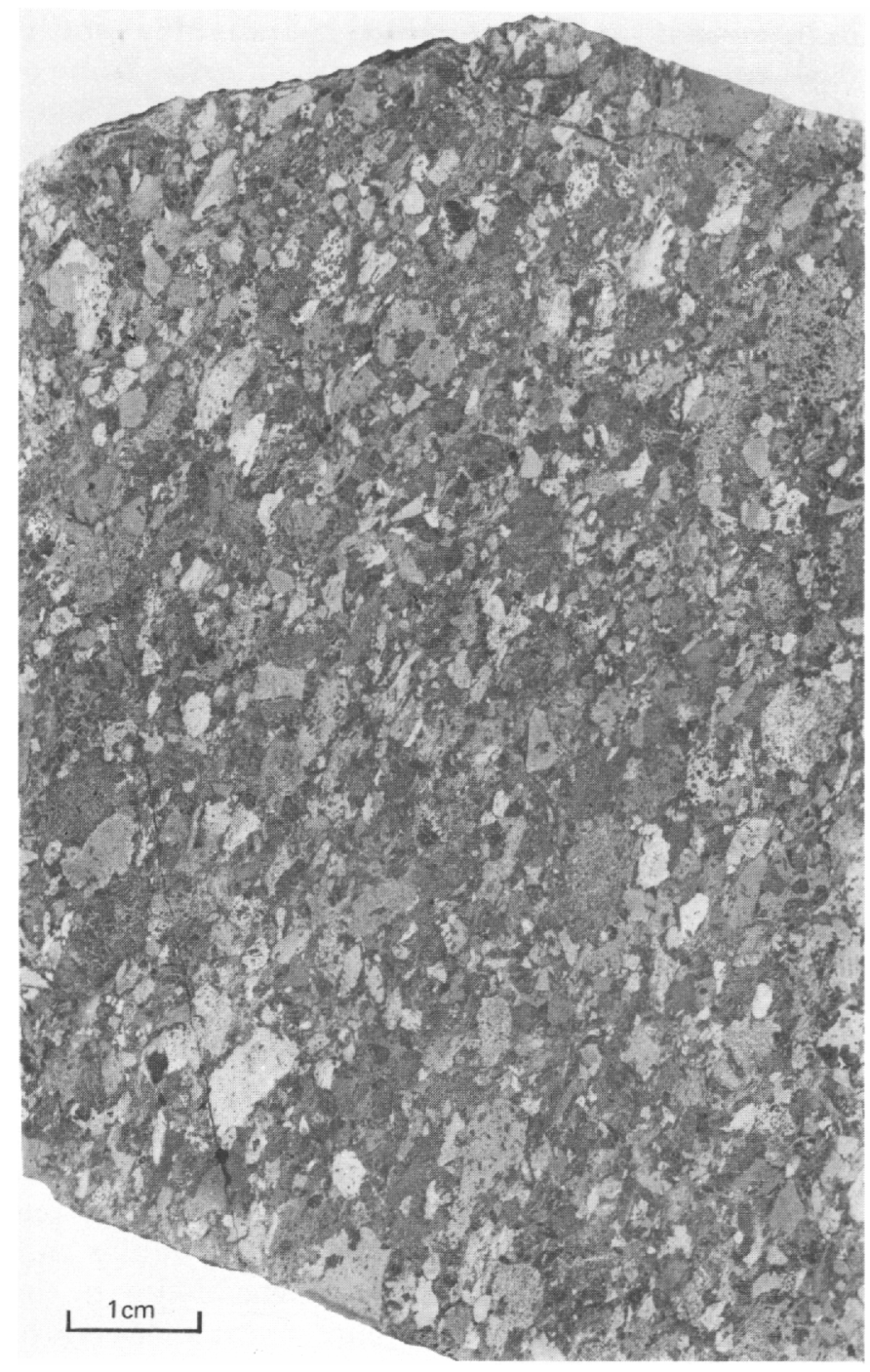

Figure 2.-Andesitic metatuff on east side of Dark Canyon (loc. 1726). Note the subangular shape of the fragments.

metabasalt with similar plagioclase phenocrysts as occur in the main body.

Chemical analyses of a sample from the uppermost part of the metabasalt exposed along the river east of the mouth of Berry Creek (loc. M156) have been published by Hietanen (1951, table 1$)$.

\section{META-ANDESITE}

Four large (3-5 km long) and several small bodies of meta-andesite are exposed in the southwest half of the Berry Creek quadrangle. The meta-andesite is greenish gray, fine to medium grained, and very hard and appears massive in most outcrops. However, sawed surfaces of hand specimens from many "massive" outcrops reveal pyroclastic structures. Volcanic breccia and agglomerate with round bombs are common in the central part of the quadrangle

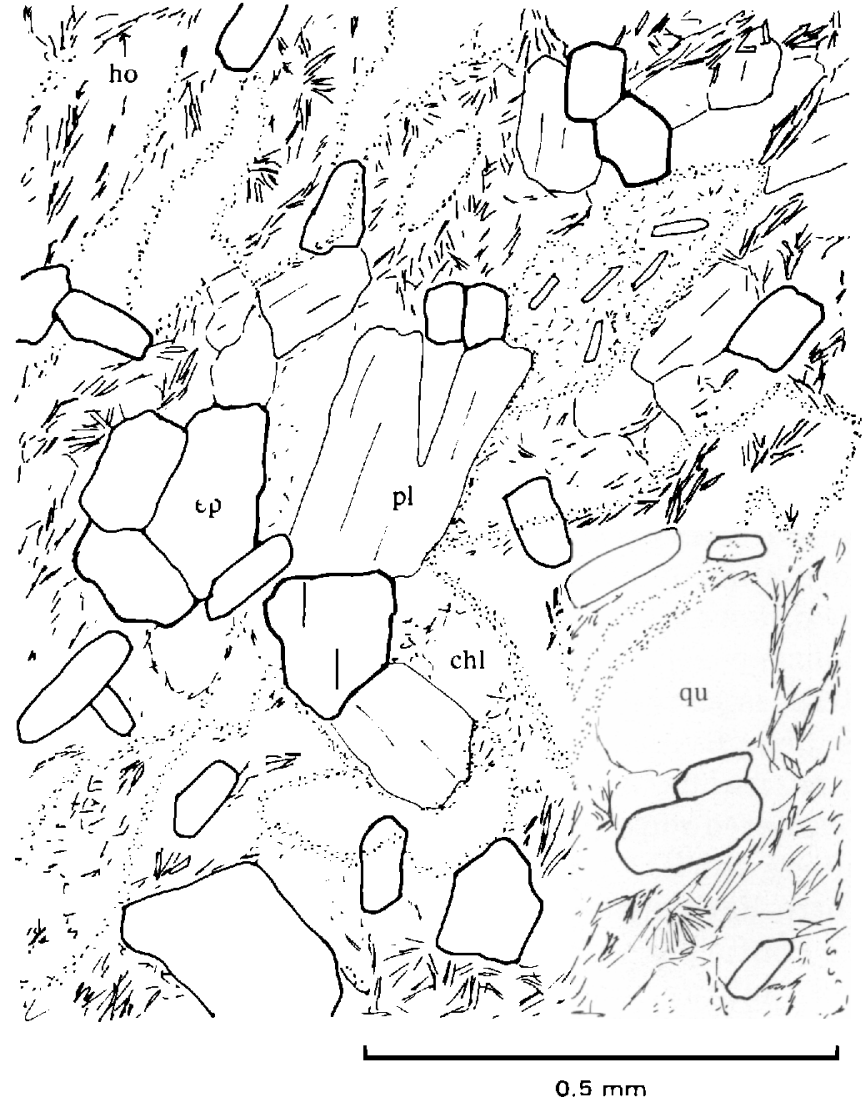

Figure 3.-Outlines of relict shards, shown by rows of dustlike material, in metatuff of the Bloomer Hill Formation (loc. 1800). pl, albitic plagioclase; ep, epidote; chl, chlorite; ho, needles of amphibole; qu, quartz.

and tiny elongate fragments $(1 / 2-2 \mathrm{~mm}$ long) make up most of the meta-andesite in the west-central part. Subangular fragments of lapilli size $(1 / 2-1 \mathrm{~cm}$ long) constitute some of the meta-andesite along Dark Canyon creek (fig. 2). Shards are preserved in a layer interbedded with fine-grained metatuff in the southwestern part of the quadrangle (fig. 3).

In the central part of the quadrangle, sorting according to the size of fragments is poor: bombs and large fragments are $2-20 \mathrm{~cm}$ long; the matrix contains many tiny ( $1-5 \mathrm{~mm}$ long) subangular fragments. This type of pyroclastic rock is exposed, for example at Bloomer Hill Lookout (fig. 4) and at Intake (loc. 1729).

Thin sections show that most bombs in the central part of the quadrangle consist of amygdaloidal porphyritc meta-andesite in which the phenocrysts are plagioclase and the groundmass consists of hornblende, chlorite, epidote, albite, leucoxene, and some magnetite. In contrast to the Paleozoic metaandesite, these rocks are not much deformed even if they are thoroughly recrystallized. The phenocrysts 


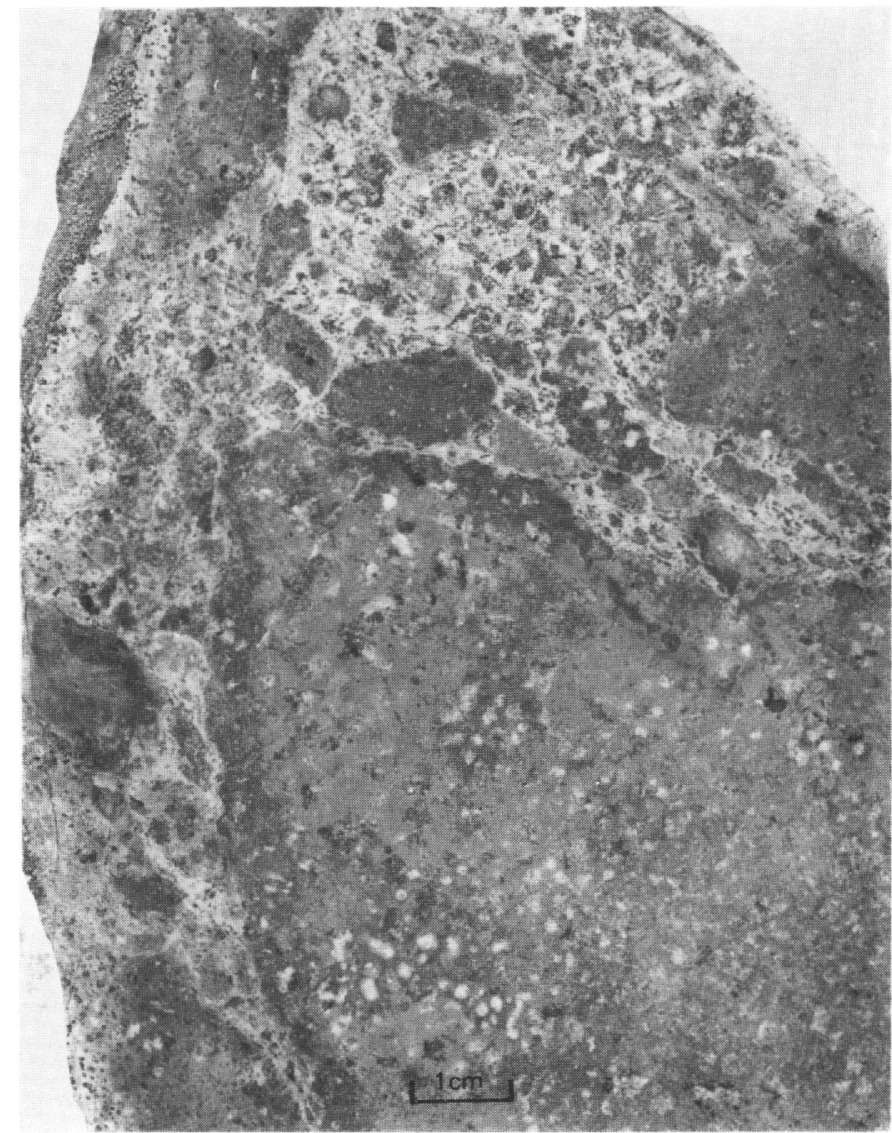

Figure 4.-Pyroclastic structures in meta-andesite at Bloomer Hill Lookout (loc. 1755). Small subangular fragments are in the matrix between large rounded volcanic bombs that contain numerous quartz amygdules.

of plagioclase retain their euhedral shapes and straight crystal boundaries but have been recrystallized to a mixture of epidote, albite, muscovite, and some biotite. The groundmass is fine grained and clouded by tiny grains of leucoxene. The mineralshornblende, chlorite, albite, and epidote-can be identified only under high magnification. Small prisms of pale-green hornblende in random arrangement form a felted texture; chlorite and albite are interstitial. Tiny grains of epidote form fine-grained cloudy clusters or are scattered. Patches clouded by leucoxene seem isotropic under a low-power lens. Amygdules consist of chlorite and epidote or of epidote and quartz.

In the western part of the quadrangle, fragments in metatuff consist of porphyritic or fine-grained meta-andesite in which phenocrysts of albite with euhedral shapes and straight crystal faces are embedded in a fine-grained groundmass that consists of small prisms of amphibole, laths of albite, and tiny grains of epidote. In many fragments, particularly in those of lapilli size (loc. 1726), the flow structure of the original lava is preserved as subparallel orientation of small albite laths. Amphibole prisms show random arrangement and may traverse the albite laths. Tiny epidote grains are scattered among the amphibole and albite. Larger ( $1 / 2-2 \mathrm{~mm}$ long) subhedral to anhedral grains of epidote are clustered with chlorite or with chlorite and amphibole. Most of these clusters have irregular outlines, but some suggest relict crystal faces of augite. All these clusters are probably alteration products after pyroxene. Magnetite, sphene, and leucoxene are the common accessory minerals. Small round amygdules, where present, consist of chlorite and epidote, chlorite and quartz, calcite, or other combinations of these minerals.

In all these rocks, the matrix between the fragments is thoroughly recrystallized and consists of a mixture of hornblende, epidote, albite and chlorite in grains larger than those in the fragments. This larger grain size was probably attained during recrystallization because of more volatiles in the matrix.

The homogeneous meta-andesite that probably represents flows is coarser grained than the metaandesite in the bombs of pyroclastic rocks. Hornblende prisms are 0.1-0.2 mm long and randomly arranged; albite and chlorite are interstitial. Epidote grains range from very small to $0.5 \mathrm{~mm}$ long and are generally clustered. This rock contains fewer amygdules than that forming the bombs. Ophitic texture with long laths of calcic plagioclase (altered to epidote + albite) and interstitial hornblende is common in long, narrow, dikelike bodies.

Chemical analysis of meta-andesite at Intake (table 1, specimen 1729) shows high aluminum and calcium and low magnesium content. A thin section of this rock shows clusters of large grains of epidote in the matrix between fragments of porphyritic and amygdaloidal meta-andesite.

\section{METADACITE}

Much of the pyroclastic rock in the central part of the quadrangle contains about 15 percent quartz (most of it in amygdules), 20 percent albite, and 30 percent epidote. These rocks are shown as metadacite on the geologic map (pl. 1). In the outcrop they are distinguished from meta-andesite by a lighter grayish-green color and by the presence of a considerable amount of quartz.

Fragmentary structures are characteristic of all metadacite in the vicinity of Bloomer Hill. In a common type, large round bombs $(3-20 \mathrm{~cm}$ in diameter) 


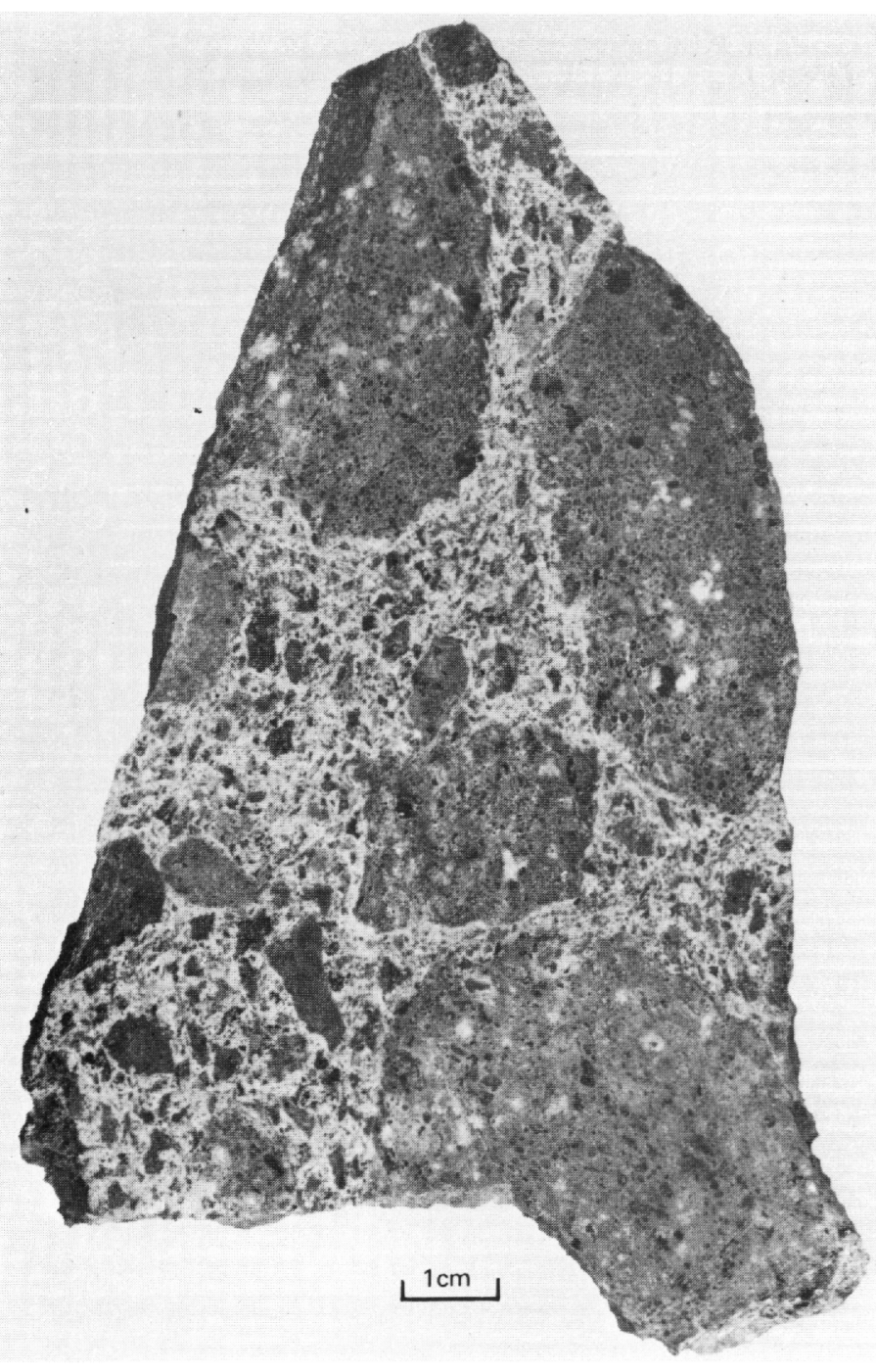

Figure 5.-Pyroclastic metadacite about $1^{1 / 2} \mathrm{~km}$ northwest of Bloomer Hill (loc. 1758). Matrix between subangular to round fragments of amygdaloidal metadacite contains numerous small fragments that are alined parallel to the original flow structure.

are embedded in a rock that contains numerous small fragments (fig. 5). Most of the large bombs consist of amygdaloidal porphyritic metadacite; the small fragments are either metadacite, metaandesite, or plagioclase.

Thin sections show that the metadacite is thoroughly recrystallized but not much deformed. The bombs consist of porphyritic rock in which large euhedral plagioclase phenocrysts are embedded in a fine-grained groundmass consisting of amphibole, albite, epidote, quartz, and chlorite. The phenocrysts are undeformed with straight crystal boundaries, but they have altered to a mixture of albite, muscovite, and epidote. In the groundmass, palegreen amphibole needles form a felted mesh, and

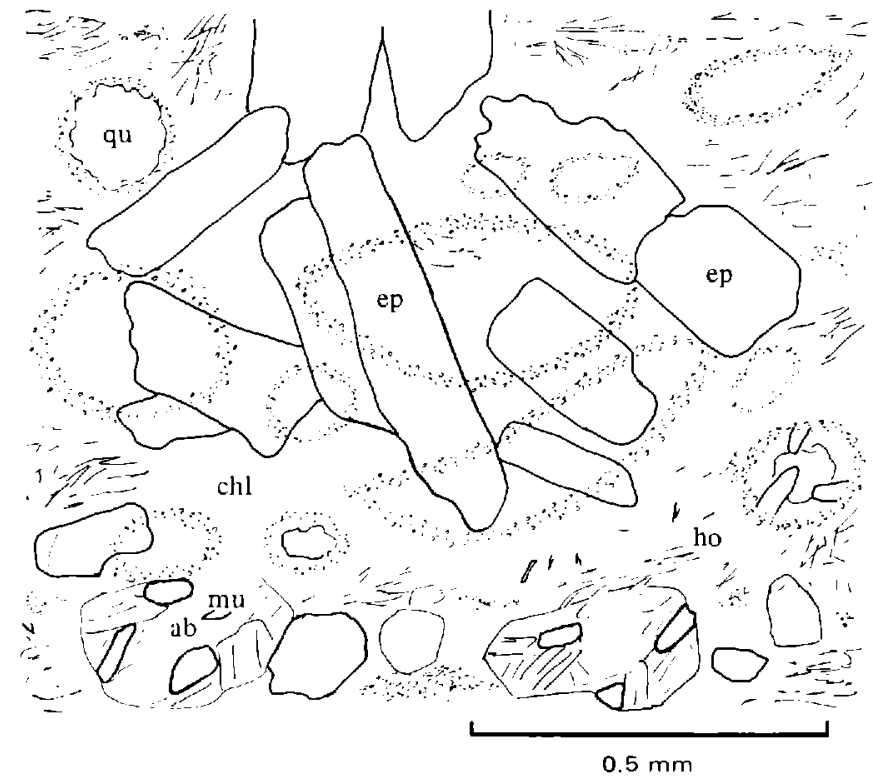

FiguRE 6.-Matrix of pyroclastic metadacite shown in figure 5. In thin section relict outlines of former vesicles appear as broad lines of tiny grains of sphene and dustlike particles (shown by dots). Metamorphic minerals, chlorite (chl) and epidote (ep), have grown across these relict outlines without disturbing them. Quartz (qu) fills some of the former vesicles. Plagioclase has altered to albite (ab), muscovite (mu), and epidote. Amphibole (ho) is in small needles.

albite is either interstitial or in small laths. Epidote is in small scattered grains among the amphibole and albite or clustered with chlorite.

The matrix between the fragments is medium grained and consists of albite, epidote, amphibole, and chlorite. In places, rows of tiny grains of sphene and dustlike inclusions show relict flow structures and outlines of former vesicles. The metamorphic minerals, epidote and chlorite, have grown across these primary structures without disturbing them (fig. 6). These relict textures, together with wellpreserved euhedral outlines of phenocrysts, show that many large competent blocks within the Mesozoic Bloomer Hill Formation have escaped the effect of stress but not that of elevated temperature.

Chemical analysis of a large specimen of pyroclastic rock collected $1 / 4 \mathrm{~km}$ north of Bloomer Hill Lookout (table 1, specimen 1753) is similar to that of the metadacite specimen M384 collected from Bloomer Hill and published earlier (Hietanen, 1951, table 1). Regardless of the seemingly great inhomogeneity of this pyroclastic rock in outcrop, the average composition is that of a typical metadacite.

\section{METASODARHYOLITE}

A 1.5-km-wide belt of metasodarhyolite at the center of the southern border extends northward 6 
$\mathrm{km}$ to the center of the quadrangle and from there 2 $\mathrm{km}$ farther northwest. The rock is rich in quartz and albite and contains mainly biotite or chlorite as a dark constituent. Stained specimens show only a trace, if any, of potassium feldspar, except at locality 1787,1 $\mathrm{km}$ southeast of Bloomer Hill Lookout, where the groundmass contains about 10 percent interstitial untwinned potassium feldspar.

The metasodarhyolite is light gray to bluish gray and slightly foliated. It contains numerous phenocrysts of colorless or light-smoky-gray to blue quartz and light-gray to white albitic plagioclase. Thin sections show that the phenocrysts are euhedral to subhedral with straight, well-preserved crystal faces. Some of the quartz phenocrysts within shear zones are granulated, but elsewhere weak strain shadows and fractures are the only signs of deformation. Albite phenocrysts include epidote and muscovite and, rarely, biotite. The groundmass consists of quartz, albite, biotite, epidote, and some muscovite and chlorite. Magnetite is a common accessory mineral. Locally biotite and epidote show a well-developed parallel orientation, whereas albite and quartz form a mosaic of irregularly shaped grains. These textural features suggest that the orientation of biotite may reflect original flow structure. In the south-central part of the quadrangle (loc. 1835) relict fragmental texture can be recognized under the microscope. Chlorite and some muscovite separate small fragments of porphyritic sodarhyolite in which the groundmass consists mainly of small laths of albite with some tiny inclusions of epidote, muscovite, chlorite, leucoxene, and magnetite.

Metasodarhyolite with a trachytic texture is exposed near Berry Creek (loc. 1849) and to the south (loc. 1792). This rock is foliated, light to medium gray, and fine grained with a few small phenocrysts of subhedral plagioclase and quartz. Thin sections show that the groundmass consists of small laths of plagioclase (about 50 percent), flakes of chlorite ( 38 percent), interstitial quartz (12 percent), and some magnetite. Most of the plagioclase $\left(\mathrm{An}_{8}\right)$ laths and chlorite flakes have a subparallel arrangement, but some are at angles up to $80^{\circ}$ with the direction that most likely corresponds to the original flow structure. Quartz phenocrysts are granulated, and the original crystal faces are replaced by grain to grain boundaries because of strong deformation and thorough recrystallization near the Bald Rock pluton. The total absence of potassium-bearing minerals in this rock indicates that it is exceptionally low in $\mathrm{K}_{2} \mathrm{O}$. It is possible that the potassium-poor trend of this sodarhyolite was accentuated during the con- tact metamorphism.

Chemical composition of porphyritic metasodarhyolite $1 \mathrm{~km}$ north of Berry Creek School (loc. 1805, table 1) is similar to that of the sodarhyolite at the mouth of Berry Creek (Hietanen, 1951, table 1, loc. 147). Comparison of specimen 1805 with the metarhyolite of the Horseshoe Bend Formation (table 1, specimen 1797) shows less potassium and calcium and more sodium in specimen 1805.

Metasodarhyolite south of Linden Spring (locs. $1749,1751)$ contains considerably more epidote than is present elsewhere. Large epidote grains are clustered with albite phenocrysts, and the groundmass is studded with tiny grains of epidote. Flakes of chlorite and biotite show a well-developed parallel orientation. Many albite phenocrysts and elongate clusters consisting of epidote, albite, and granulated quartz as well as small elongate clusters of sphene are enveloped by biotite and chlorite. It seems that the original flow structure was accentuated by a later deformation and recrystallization.

\section{METATUFF AND TUFFACEOUS METASEDIMENTARY ROCKS}

A few discontinuous layers of fine-grained foliated metatuff are interbedded with the Bloomer Hill Formation. These rocks range in composition from basaltic and andesitic to dacitic and sodarhyolitic. Some occurrences are thin bedded, but in the others a well-developed foliation is the only recognizable planar structure. Most metatuffs are greenish or bluish gray or grayish green, the hues becoming greener with increasing epidote content and lighter with increasing quartz and albite. The basaltic metatuff consists mainly of amphibole with subordinate amounts of albite, epidote, chlorite, and magnetite. The andesitic metatuff is rich in epidote with much less amphibole and less magnetite than is present in the basaltic metatuff. With an increase in albite and quartz and a decrease in amphibole and epidote, the andesitic metatuff grades to dacitic metatuff. The sodarhyolitic metatuff is rich in quartz and albite. Biotite instead of amphibole is the major dark constituent, and muscovite, chlorite, and epidote are subordinate.

Fine-grained hornblende-rich layers $0.7-1 \mathrm{~km}$ south of the mouth of French Creek include basaltic metatuff and tuffaceous metasediment. The northernmost layer of metatuff, which is just south of a long body of metagabbro, consists of agglomerate in which fragments of metabasalt are mineralogically similar to the Mesozoic metabasalt farther south. These fragments are strongly elongate parallel to the lineation but have angular cross sections (fig. 7). The 

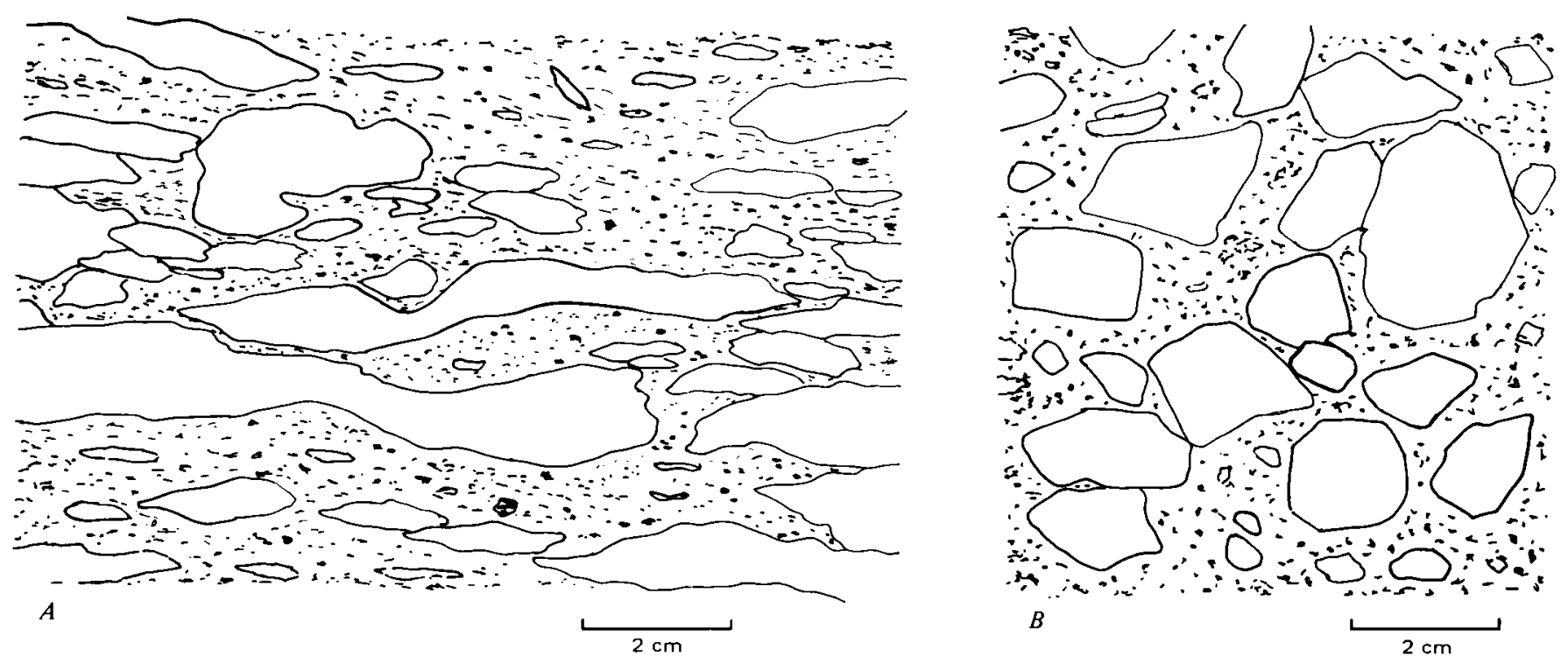

FIGURE 7.-Sketches showing elongate metabasalt fragments in agglomerate of the Bloomer Hill Formation $0.7 \mathrm{~km}$ south of the mouth of French Creek (loc. 1881). A, Section parallel to lineation. B, Cross section.

tuffaceous layers are thin bedded and well foliated. They consist of plagioclase $\left(\mathrm{An}_{15}\right)$, hornblende, chlorite, biotite, epidote, quartz, and magnetite. Interbedded metasedimentary layers contain more quartz and less hornblende and chlorite. Subhedral prisms of hornblende, strongly pleochroic in blue-green and green, are either clustered or scattered randomly in a fine-grained granoblastic groundmass of plagioclase and quartz. Transecting foliation is apparent in layers that include sedimentary material.

\section{METAMORPHOSED INTRUSIVE ROCKS}

A sequence of older intrusive rocks ranges from serpentine and peridotite through metagabbro to metadiorite and metatrondhjemite. These rocks are petrologically similar to the metamorphosed intrusive rocks described from the Pulga and Bucks Lake quadrangles (Hietanen, 1973a). Therefore only some local features are pointed out here.

\section{CLTRAMAFIC: ROCKS}

Long thin bodies of serpentine and talc schist occur along and parallel to the faults that make up the Big Bend fault zone, which traverses the northern part of the Berry Creek quadrangle in a westnorthwest direction. Several north-northwest-trending small bodies of ultramafic rocks, some parallel to the faults, are along the north border of the quadrangle. The serpentine at the Hornet mine in $\mathrm{SE}^{1 / 4}$ sec. 20, T. 22 N., R. 5 E. is a southern extension of a large body in the Pulga quadrangle. The thin sheetlike masses and the border zones of large bodies consist mainly of antigorite, talc, and magnesite, indicating an advanced state of steatitization. In the central part of the thick masses all three serpentine minerals-antigorite, lizardite, and chrysotile-are present, and talc fills the cracks and joints and forms pods near them. Chromite and magnetite occur as accessory minerals.

Black coarse-grained hornblendite with pods of white calcite is exposed next to a talc schist $3 / 4 \mathrm{~km}$ west of the mouth of Stony Creek. This hornblendite consists of about 80 percent pale-green to green hornblende, 10 percent chlorite, and 10 percent calcite. Some relict pyroxene is included in a few hornblende crystals. Chlorite and calcite are interstitial. Chlorite is transected by tremolite needles, and the ends of many hornblende crystals are rimmed by tremolite. The composition and mineralogy suggest that this rock was originally pyroxenite.

\section{METAGARBRO AND METADIORITE}

Two small masses of metagabbro, each about 1 $\mathrm{km}^{2}$ in area, are in the northernmost part of the quadrangle. Several dikelike bodies are in the metavolcanic rocks within the Big Bend fault zone, some of them next to serpentine bodies. A few small masses are within the Bloomer Hill Formation. Some of the metagabbro, such as that east of Intake, is genetically associated with nearby basaltic metaandesite and differs from the extrusive rock only in its coarse equigranular or diabasic texture. Metagabbro west of Last Chance Creek and that west of Stony Creek include lenses of fine-grained hornblende-rich rock similar to the metabasalt next to them. Thin sections show that the metagabbro con- 
sists of 40-60 percent green hornblende, 15-30 percent albitic plagioclase, $20-30$ percent epidote, and some quartz, magnetite, sphene, and leucoxene. Segregations of hornblende to form hornblendite are common. Hornblende is in light-green to bluishgreen prisms that have ragged ends and are randomly arranged. Albitic plagioclase is in subhedral to anhedral grains and includes numerous small grains of epidote. Much of the epidote is in small scattered or clustered grains that are clouded by leucoxene. Some clusters consist of large clear grains.

In places metagabbro grades in to a lighter colored metadiorite that contains less hornblende and more plagioclase and epidote than the main part of the rock. For example, the central part of the metaigneous mass east of Stony Creek is dioritic consisting of 60-70 percent plagioclase and epidote, 25-30 percent hornblende, some quartz and magnetite. A dikelike body of greenish-gray medium-grained gabbroic metadiorite north of the Big Bend Road (loc. 1722 ) is texturally and mineralogically similar to the metagabbro farther east (loc. 1720) except for less hornblende and more plagioclase, epidote, and quartz in the metadiorite. Most of the epidote in this gabbroic metadiorite occurs as inclusions in plagioclase. Hornblende prisms are smaller and less numerous than in the metagabbro.

The metadiorite east of Jarbo Gap appears very similar to the nearby basaltic meta-andesite in outcrops except for a somewhat coarser grain size in the metadiorite. Study with a hand lens reveals a subophitic or equigranular texture. Thin sections show that plagioclase is albitic and occurs in stubby laths, 1-2 $\mathrm{mm}$ long, and in random arrangement forming an open network in a mixture of hornblende and epidote. Hornblende is either in large anhedral crystals or in clusters of small prisms. Epidote has recrystallized as grains of medium size and is in irregularly shaped clusters between plagioclase and hornblende. Numerous small sericite flakes and a few epidote grains are included in albitic plagioclase. Sphene and ilmenite partly altered to leucoxene occur as accessory minerals.

\section{DIFFERENCES BETWEEN THE PALEOZOIC AND MESOZOIC METAMORPHIC ROCKS}

There are marked structural and textural differences between the Paleozoic and Mesozoic metamorphic rocks in general, and between the rocks of the contact aureoles of the plutons and those farther from the plutons. Moreover, all rocks within the Big Bend fault zone are strongly deformed.

\section{PRIMARY STRUCTLRES}

Primary structures such as bombs, lapilli, and volcanic breccia are well preserved in the Mesozoic metavolcanic rocks outside the contact aureoles of the Cretaceous plutons, but they are obscured by strong deformation in the Paleozoic metamorphic rocks. Subangular to round bombs with numerous round amygdules are typical of the meta-andesite and metadacite of the Mesozoic Bloomer Hill Formation (figs. 4 and 5). In the fragmentary meta-andesite along Dark Canyon and to the southeast along the North Fork of the Feather River, tiny fragments retain their angular to subangular shapes and amygdules are round or only slightly deformed. Locally, relict flow structures and outlines of shards are shown by bands of tiny inclusions of dustlike material, probably iron oxide. In the meta-andesite south of Intake, the euhedral shapes and welldeveloped crystal faces of plagioclase phenocrysts are preserved. The amygdules are round although the groundmass is weakly foliated. The original shapes of phenocrysts and amygdules are remarkably well preserved also in the metabasalt of the Bloomer Hill Formation along the North Fork of the Feather River west of Stephens Ridge although these exposures are within the contact aureole of the Bald Rock pluton. In contrast, the metabasalt of the Paleozoic Horseshoe Bend Formation has been recrystallized into a well-foliated amphibolite in which all primary structures have been obliterated.

Bedding is preserved in all thin-bedded strata such as some of the metatuff, tuffaceous metasediment and most of the quartzite, phyllite, and limestone. Since it is equally well preserved in both the Paleozoic and Mesozoic rocks, it does not serve as a distinguishing feature.

\section{STRUCTURES DUE TO DEFORMATION}

The Big Bend fault zone that traverses the northern part of the Berry Creek quadrangle in a westnorthwest direction has several branches that have sliced the metamorphic rocks of the Horseshoe Bend Formation. Each branch is accompanied by thin bodies of serpentine and talc schist or in places by metagabbro and metadiorite. The displacement along the fault zone was down on the southwest side, bringing the Mesozoic Bloomer Hill Formation into fault contact with lower units of the Permian(?) Horseshoe Bend Formation in the central part of the quadrangle.

Foliation is the most prominent structural feature in the study area. It is well developed in all rocks within the Big Bend fault zone and in the contact 
aureoles of the plutons. The differences between the Paleozoic and Mesozoic metamorphic rocks become apparent outside these aureoles. Foliation can be measured in all Paleozoic rocks, but it generally is stronger in metatuff and phyllite than in metabasalt, and the central parts of thick metabasalt units outside the contact aureoles of the plutons tend to be massive. In contrast, foliation in the Mesozoic metavolcanic rocks is poorly developed except near the Bald Rock pluton where all rocks are strongly foliated.

The attitudes of the bedding and foliation indicate that the rocks are isoclinally folded and that the foliation is parallel to the axial planes. The distribution of rock types and a few measured minor fold axes suggest that the fold axes are nearly horizontal in the western part of the area but deviate considerably from the regional trends near the Cretaceous plutons. The rise of the magmas of these large plutons has overprinted the rocks in the contact aureoles, 1-2 km wide, with a strong second deformation. Steep lineation and second folding on steeply plunging axes are characteristic in the Mesozoic as well as in the Paleozoic rocks. However, there are marked differences in the orientation of these secondary structures in the contact aureoles of the Bald Rock and Merrimac plutons. Near the Bald Rock pluton the dips of the beds and the plunge of the $B$ lineation are to the northwest away from the pluton owing to a domelike rise of this pluton and a fairly high level exposure. In contrast, bedding southwest of the Merrimac pluton dips $40^{\circ}-70^{\circ} \mathrm{NE}$ towards the pluton or is nearly vertical, and the plunge of the lineation is generally to the northeast. These differences are consistent with the concept that a deeper level is exposed in the Merrimac pluton.

\section{METAMORPHISM}

Beyond the contact aureoles of the Bald Rock and Merrimac plutons the Paleozoic rocks are generally more thoroughly recrystallized than the Mesozoic ones. The groundmass in the Paleozoic metavolcanic rocks is granoblastic, and the metamorphic minerals such as epidote, amphibole, chlorite, albite, and quartz are in well-defined individual grains. In contrast, the groundmass of the Mesozoic metavolcanic rocks is a felted mixture of tiny amphibole needles, patches of clouded fine-grained epidote, and interstitial chlorite, albite, and quartz all with hazy outlines. Thus the difference in the groundmass is mainly textural. Phenocrysts exhibit mineralogical as well as textural differences due to an incomplete reconstitution of the Mesozoic rocks. In the augite basalt of the Bloomer Hill Formation in the south- western part of the quadrangle, euhedral augite phenocrysts are well preserved or are altered to chlorite or to a mixture of chlorite and epidote only along the borders. In the Paleozoic rocks recrystallization of phenocrysts was complete, and their euhedral shape was generally destroyed. Plagioclase phenocrysts in the Mesozoic rocks are well preserved and contain only small inclusions of epidote and sericite, whereas in the Paleozoic rocks plagioclase recrystallized as a mixture of epidote and albite and generally lost its euhedral shape.

These textural and mineralogic differences indicate that the Paleozoic rocks must have been deformed and recrystallized before the Mesozoic volcanic rocks erupted. The Paleozoic rocks sustained a second period of metamorphism during the Nevadan orogeny (Jurassic) when the Mesozoic Bloomer Hill Formation was recrystallized. Closely similar temperatures prevailed during the first and second periods of metamorphism, producing mineral assemblages of the upper greenschist facies. Deeper burial of the Paleozoic rocks could account for their more thorough recrystallization.

The contact metamorphism around the Cretaceous plutons constituted a third period of metamorphism for the Paleozoic rocks and a second period for the Bloomer Hill Formation. Minerals of the epidoteamphibolite facies crystallized in contact aureoles 1$2 \mathrm{~km}$ wide, and contact effects such as a larger grain size and more thorough recrystallization can be detected as far as $4 \mathrm{~km}$ beyond the contacts. Cordierite crystallized with andalusite in the biotite schist in the Pulga quadrangle northwest of the Merrimac pluton; this mineral assemblage indicates physical conditions typical of the amphibolite facies (Hietanen, 1973a, 1967). Staurolite instead of cordierite occurs as a stable constituent with andalusite, biotite, and quartz in the outer part of this contact zone.

Changes due to the contact metamorphism are especially striking in the Mesozoic rocks west of the Bald Rock pluton. The augite basalt in the western part of the quadrangle contains unaltered primary augite phenocrysts in a felted groundmass of tiny amphibole needles and epidote grains dusted by leucoxene. In contrast, the metabasalt near the Bald Rock pluton was recrystallized as amphibolite with clear stubby crystals of hornblende, epidote, and plagioclase that has a lower anorthite content than the original plagioclase. Next to the pluton all tuffaceous layers recrystallized to a hornblende gneiss or to a well-foliated amphibolite making the textural distinction between the Paleozoic and Mesozoic metatuff impossible. 
Most of the metasodarhyolite of the Bloomer Hill Formation is in the outer contact aureole of the Bald Rock pluton. Over a distance of $2 \mathrm{~km}$ the groundmass generally becomes coarser grained toward the pluton and the anorthite content of the plagioclase increases from about $A n_{5}$ to about $A n_{15}$. The percentage of epidote, chlorite, and muscovite decreases and that of biotite increases. An exception is metasodarhyolite at Berry Creek (locs. 1849 and 1792). In this rock, chlorite instead of biotite crystallized because of an exceptionally low $\mathrm{K}_{2} \mathrm{O}$ content.

\section{CHEMICAL COMPOSITION}

Chemical analyses (table 1) show that all metavolcanic rocks of the Bloomer Hill Formation are poor in potassium. There is less than 1 percent $\mathrm{K}_{2} \mathrm{O}$ in the silicic end member, the metasodarhyolite on Berry Creek (specimen 1805), and only a fraction of a percent in the other analyzed samples, the molecular ratio of potassium to total alkalies (K-value) being 0.1 or less. The K-value of the metarhyolite of the Horseshoe Bend Formation (specimen 1797) is 0.18; it contains less sodium and more potassium and calcium than the metasodarhyolite of the Bloomer Hill Formation. In other respects the chemistry of these silicic end members are much alike. Comparison of the chemical composition of the most mafic members of these two formations (table 1, specimens 1838 and 1826) shows a lower content of iron and higher content of magnesium and calcium in the Bloomer Hill Formation (specimen 1838).

The normative quartz-feldspar content of the analyzed samples is shown in ternary Q-Or-Ab and QOr-Pl diagrams (figs. $8 A, B$ ). All samples plot near the quartz-plagioclase line, far from the orthoclase corner. The mafic members of both formations are slightly deficient in quartz as shown by negative normative quartz. Analyses published earlier (Hietanen, 1951) are shown for comparison. In the metasodarhyolite of the Bloomer Hill Formation, 79 percent of the total normative feldspar is albite (anal. 1805 in the Or-Ab-An diagram, fig. 8C) and only 8.4 percent orthoclase, a normative feldspar content similar to that in trondhjemites. In contrast, the metarhyolite of the Horseshoe Bend Formation (anal. 1797 in fig. $8 C$ ) contains only 54.8 percent normative albite and 11.8 percent normative orthoclase. The intermediate and mafic members contain 45-66 percent normative anorthite and less than 6 percent normative orthoclase. All these rocks are rich in normative plagioclase.

In the QFM diagram all analyses plot near the $\mathrm{F}$ corner (fig. $8 D$ ); points for the metarhyolite are clustered near the QF line and those for the mafic rocks near the MF line. Metadacite at Bloomer Hill (specimens 1753 , M384) contains only slightly less normative ferromagnesian minerals and more quartz than the mafic members. The normative mineral content of the meta-andesite at Intake (specimen 1729 ) is close to that of the metadacite, except that it is exceptionally rich in normative anorthite as shown in the Or-Ab-An diagram (fig. $8 C$ ). This may be due to segregation of epidote during the metamorphism.

\section{TRACE ELEMENTS}

There is no essential difference in the trace-element content between the end members of the Horseshoe Bend and Bloomer Hill Formations (table 1). Metabasalts from both formations contain considerable amounts of vanadium, copper, chromium, and strontium. The silicic end members contain moderate amounts of barium, strontium, and zirconium. The intermediate members show features common to both end members; the concentrations of vanadium and strontium are similar to those in the mafic end members, and the concentrations of barium, copper, and zirconium are intermediate between the mafic and silicic end members.

\section{ALTERED PLUTONIC ROCKS}

A small body of altered gabbro along the south border of the quadrangle and a small mass of altered trondhjemite at Big Bend are less deformed than the meta-igneous rocks and are presumably younger. These small masses are probably correlative with the altered plutonic rocks of probable Jurassic age north of the Lumpkin pluton on the east side of the Bald Rock pluton (Hietanen, 1976).

\section{ALTERED GABBRO}

The altered gabbro on the south border of the Berry Creek quadrangle is the north end of a larger mass that has dark-gray, hornblende-rich border zones and a lighter colored center containing more plagioclase and less hornblende. Good exposures on the roadcuts along Ponderosa Way show that this rock is coarse grained and undeformed and consists mainly of subhedral amphibole and plagioclase grains. In thin sections the centers of plagioclase grains appear altered, consisting of an opaque mixture of clay minerals(?) and epidote. The rims are albitic plagioclase. Amphibole is in large blocky prisms that include magnetite and some sphene and epidote. Most of the amphibole is colorless tremolite with mottled or streaky interference colors; some grains 

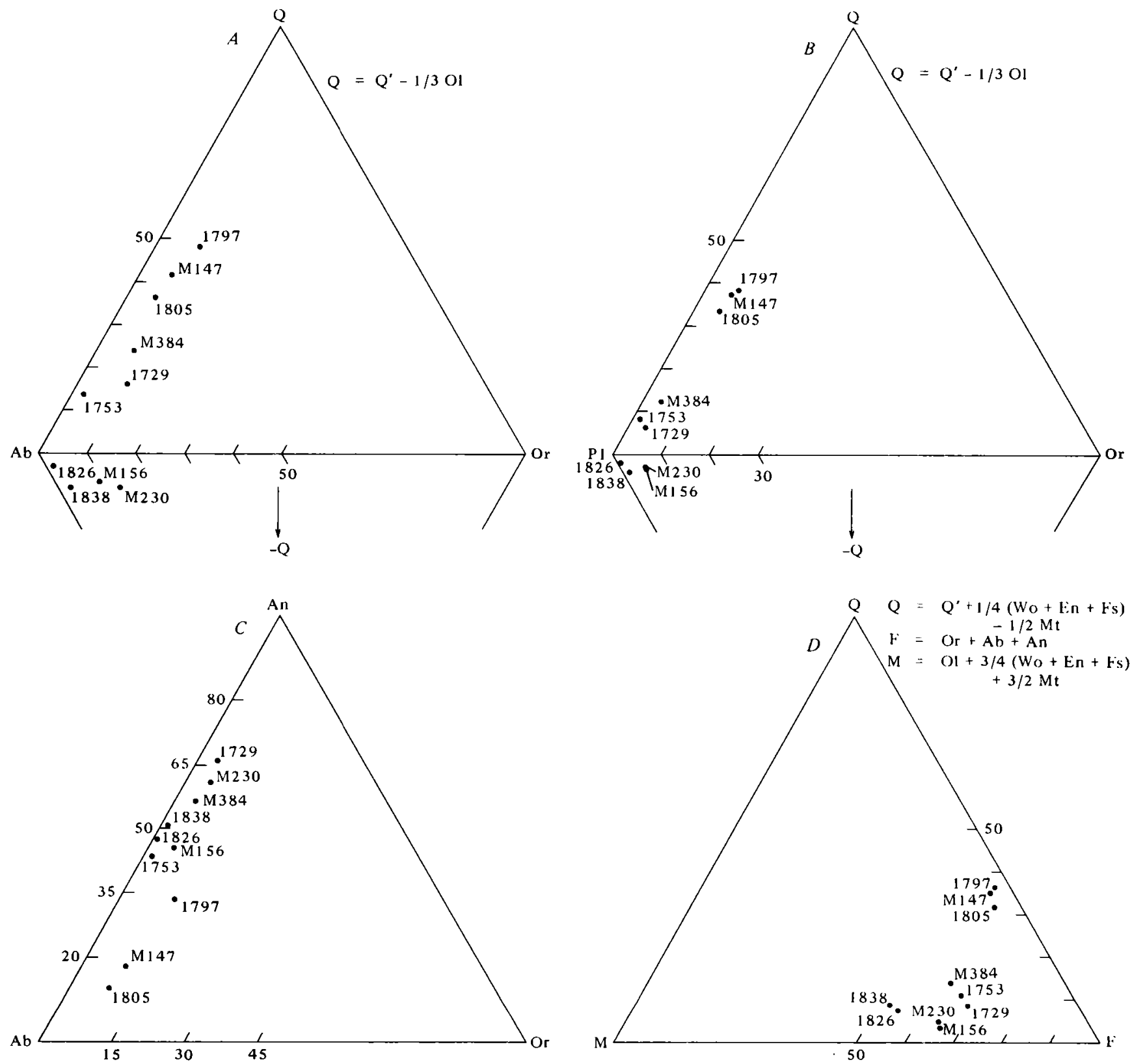

FiguRE 8.-Ternary diagrams showing variation in composition, in molecular percentages, of metavolcanic rocks of the Berry Creek quadrangle. Numbers refer to analyses in table 1; those with prefix $M$ are from Hietanen (1951). $A$, Normative quartz minus olivine $\left(Q^{\prime}-1 / 3 \mathrm{Ol}\right)$, albite $(\mathrm{Ab})$, and orthoclase $(\mathrm{Or})$. $B$, Normative quartz minus olivine $\left(\mathrm{Q}^{\prime}-1 / 3 \mathrm{Ol}\right)$, plagioclase $(\mathrm{Ab}+\mathrm{An})$, and orthoclase (Or). C, Normative anorthite (An), albite (Ab), and orthoclase (Or). D, Normative quartz (Q), mafic minerals as orthosilicates $(M)$ and feldspars $(F)$.

have green border zones and include patches of lightgreen hornblende.

Interstitial grains of quartz, which show slight strain shadows but are not granulated, make about 2 percent of the rock. a few grains of chlorite with gray interference color are next to hornblende.

\section{ALTERED TRONDHJEMITE}

A small mass of altered trondhjemite is exposed east of Surcease mine at Big Bend. This rock is coarse grained with clusters of green epidote and chlorite in a light-greenish-gray to white mixture of plagioclase and quartz. Plagioclase $\left(\mathrm{An}_{5}\right)$ is in large subhedral 
crystals that are studded with small flakes of muscovite and grains of epidote. Quartz is either interstitial or forms clusters of grains of medium size, some of which have euhedral crystal faces toward the neighboring plagioclase. Chlorite makes up about 7 percent of the rock. It includes large grains of epidote, sphene, and calcite; numerous tiny needles of rutile and sphene are along its cleavage planes. Most of the chlorite is probably an alteration product after hornblende and some after biotite. Ilmenite is altered to sphene and leucoxene. Magnetite and apatite occur as accessory minerals. This trondhjemite is mineralogically similar to the metatrondhjemite in the American House quadrangle, about 30 $\mathrm{km}$ to the east, but its texture is different. It is not strongly deformed as are the occurrences farther east, rather the hypidiomorphic texture is well preserved. Plagioclase and even some of the quartz are subhedral. The absence of strong deformation is in agreement with its younger age as compared with the eastern occurrences. The altered trondhjemite at Big Bend is a plutonic equivalent of the Mesozoic metasodarhyolite exposed to the southeast, whereas the eastern occurrences are associated with the metasodarhyolite of the Paleozoic (Devonian?) Franklin Canyon Formation.

\section{PLUTONIC ROCKS}

The southwestern part of the Merrimac pluton and the northwestern part of the Bald Rock pluton are exposed in the eastern part of the Berry Creek quadrangle (pl. 1).

\section{MERRIMAC: PLUTON}

The southwestern part of the Merrimac pluton is well exposed in roadcuts along a logging road that passes from French Creek over Swayne Hill to Chino Creek and to Last Chance Creek. Most of the rock along this road is light-gray coarse-grained tonalite in which the major constituents-plagioclase, quartz, hornblende, and biotite-can easily be identified in the field (fig. 9). At Chino Creek a medium-grained variety with large hornblende crystals and with inclusions of hornblende-rich quartz diorite is widespread.

Specimens stained in the laboratory to distinguish feldspars show that the tonalite contains 3-5 percent potassium feldspar and that the percentages of the major constituents are: plagioclase 56-58, quartz 24-26, hornblende + biotite 10-15 (Hietanen, 1976). A somewhat lighter colored variety with less dark

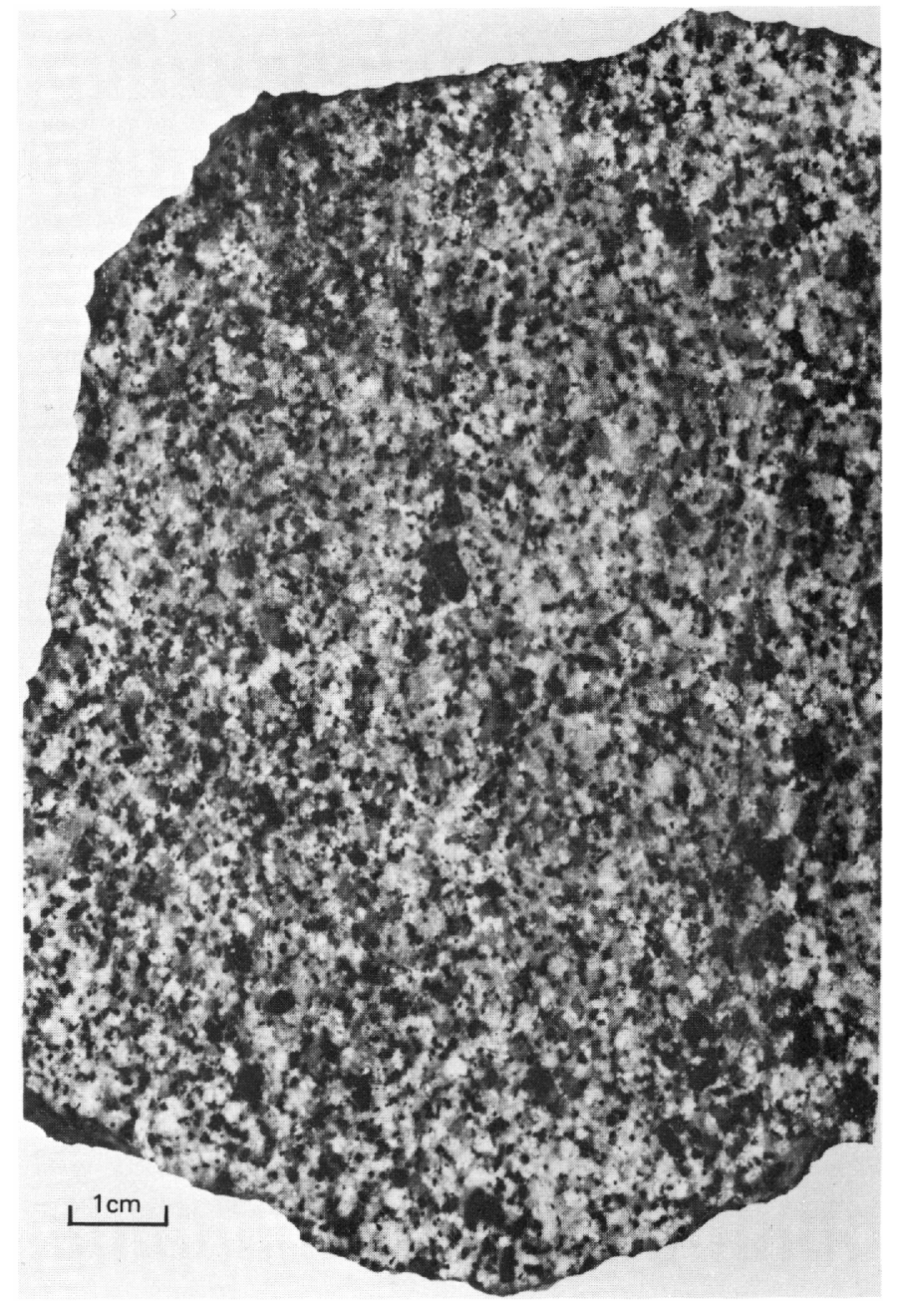

Figure 9.-Cut surface of tonalite in the south western part of the Merrimac pluton (loc. 1613). Dark-colored minerals are hornblende and biotite; light-colored minerals are plagioclase, quartz, and minor potassium feldspar.

minerals occurs locally in the central part, some of it monzotonalitic (Hietanen, 1961) and some trondhjemitic in composition. The border zone consists of hornblende-biotite quartz diorite, which has about 20 percent each quartz and combined dark constituents and 1-2 percent potassium feldspar.

Thin sections of the tonalite show that plagioclase is in blocky crystals with square cross sections. They are strongly zoned; the centers consist of $\mathrm{An}_{45}$ to $\mathrm{An}_{25}$ and narrow rims of $\mathrm{An}_{20-25}$. Polysynthetic twinning is ubiquitous. Hornblende is in subhedral to anhedral grains and is strongly pleochroic, $\gamma=$ bluish green, $\beta=$ green, and $\alpha=$ pale green. Large hornblende crystals include small grains of plagioclase and magnetite. Biotite forms large blocky 
TABLE 2.-Chemical composition, molecular norms, and trace elements of monzotonalite (specimen 1613) from the Merrimac pluton [Chemical analysis in weight percent by Edyth Engleman; spectrographic analysis by Chris Heropoulos]

\begin{tabular}{|c|c|c|c|c|c|}
\hline \multicolumn{3}{|c|}{ Chemical composition, in } & \multirow{2}{*}{$\begin{array}{c}\text { Catanorm, in } \\
\text { molecular percent }\end{array}$} & \multirow{2}{*}{$\begin{array}{c}\text { Mesonorm, in } \\
\text { molecular percent }\end{array}$} & \multirow{2}{*}{$\begin{array}{c}\text { Trace elements, } \\
\text { in ppm }\end{array}$} \\
\hline \multicolumn{2}{|r|}{ Weight percent } & cation percent & & & \\
\hline $\mathrm{SiO}_{2}$ & 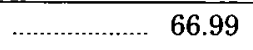 & $\mathrm{SiO}_{2} \ldots \ldots \ldots \ldots \ldots \ldots$ & $2 . \ldots \ldots$ & Quartz & $\mathrm{Ba}$ \\
\hline $\mathrm{TiO}_{2}$ & 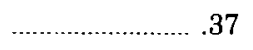 & $\mathrm{TiO}_{2} \quad \ldots \ldots \ldots \ldots \ldots \ldots . . . . .26$ & Or $\ldots \ldots \ldots$ & Orthoclase & Co ........... \\
\hline $\mathrm{Al}_{2} \mathrm{O}_{3}$ & $3 \quad \ldots \ldots \ldots \ldots \ldots \ldots \ldots \ldots$ & $\mathrm{AlO}_{3 / 2} \ldots \ldots \ldots$ & $\mathrm{Ab}$ & Albite & $\mathrm{Cr}$ \\
\hline $\mathrm{Fe}_{2} \mathrm{O}_{3}$ & 1.43 & $\mathrm{FeO}_{3 / 2} \ldots \ldots \ldots \ldots \ldots$ & 19.32 & Anorthite & $\mathrm{Cu}$ \\
\hline $\mathrm{FeO}$ & 1.82 & $\mathrm{FeO}$ & .36 & Muscovite $\quad 3.08$ & $\mathrm{Ni}$ \\
\hline $\mathrm{MnO}$ & $\ldots+\ldots \ldots \ldots \ldots . . .07$ & $\mathrm{MnO} \ldots \ldots \ldots \ldots \ldots \ldots$ & 5.17 & Biotite & $\mathrm{Sc}$ \\
\hline $\mathrm{MgO}$ & $\ldots \ldots \ldots$ & $\mathrm{MgO} \quad \ldots \ldots \ldots \ldots \ldots \ldots \ldots$ & 1.44 & Sphene & $\mathrm{Sr}$ \\
\hline $\mathrm{CaO}$ & 4.03 & $\mathrm{CaO} \ldots \ldots \ldots$ & 1.52 & Magnetite $\ldots \ldots \ldots \ldots \ldots$ & $\ldots 5 \varepsilon$ \\
\hline $\mathrm{Na}_{2} \mathrm{O}$ & $\ldots \ldots .4 .13$ & $\mathrm{NaO}_{1 / 2} \ldots \ldots \ldots$ & .53 & Apatite $\ldots \ldots \ldots \ldots \ldots . .28$ & $\mathrm{Zr}$ \\
\hline $\mathrm{K}_{2} \mathrm{O}$ & 1.93 & $\mathrm{KO}_{1 / 2} \ldots \ldots \ldots \ldots \ldots \ldots \ldots \ldots$ & .28 & Calcite …… & ...... 11 \\
\hline $\mathrm{P}_{2} \mathrm{O}_{5}$ & $\ldots \ldots \ldots \ldots \ldots$ & $\mathrm{PO}_{5 / 2} \ldots \ldots \ldots \ldots \ldots \ldots \ldots$ & .03 & & \\
\hline $\mathrm{CO}_{2}$ & $\cdots \cdots \cdots \cdots \cdots$ & $\mathrm{CO}_{2} \ldots \ldots \ldots \ldots \ldots \ldots \ldots$ & $10 . . .101$ & Total ……........ 100.01 & \\
\hline $\mathrm{H}_{2} \mathrm{O}^{+}$ & .57 & $(\mathrm{OH}) \ldots \ldots \ldots \ldots \ldots \ldots \ldots \ldots$ & & & \\
\hline $\mathrm{H}_{2} \mathrm{O}^{-}$ & .26 & & & & \\
\hline Tota & al ……..... $\overline{99.79}$ & Total ….......... 100.01 & & & \\
\hline
\end{tabular}

flakes and is strongly pleochroic in dark brown and yellowish brown. Quartz is in large anhedral grains or in clusters of grains of medium size. Potassium feldspar is interstitial, filling the triangular spaces between the other minerals and extending as thin walls between the large blocky plagioclase crystals. Larger grains show microcline twinning, and myrmekite is common between the plagioclase and microcline, which suggests that it crystallized with potassium feldspar from the last eutectic melt. Subhedral grains of epidote are clustered with biotite and hornblende. Some small flakes of muscovite are included in plagioclase. Magnetite, sphene, and apatite are the common accessory minerals.

Chemical analysis of specimen 1613 (table 2) from Chino Creek shows a considerable amount of potassium. Much of it is in potassium feldspar that is segregated in discontinuous streaks, $3-4 \mathrm{~cm}$ wide, parallel to the foliation. In composition and mineralogy this rock is similar to the inner contact aureole of the Grizzly pluton to the north and to the centers of the neighboring Granite Basin and Cascade plutons in the northeast and southeast, respectively (Hietanen, 1973a, 1976). In the Or-Ab-An diagram (fig. 10) it plots among these rocks on the quartz dioritequartz monzonite trend line. The trace-element content of the specimen 1613 (table 2), however, is different from that of this group of rocks: the chromium content is much higher, and barium and strontium contents are lower, corresponding to the trace-element content in the more mafic border zones of the others plutons.

\section{BALD ROCK PLUTON}

The northwestern part of the Bald Rock pluton consists of coarse-grained light-colored trondhjemite that grades to tonalite and quartz diorite toward the pluton border. As in the Merrimac pluton, the darker border zone on the west side is much thinner than it is on the east side of the pluton. The contact with metamorphic wallrocks is conformable; it follows a quartzite unit of the Permian(?) Horseshoe Bend Formation in the northwest and the neighboring metavolcanic layers in the north and in the west. The border zone of the pluton is strongly foliated; the platy structure parallels the contact and is in places accentuated by sheetlike remnants of wallrocks, whose bedding or foliation is parallel to the foliation of the enclosing plutonic rock. The contact between the quartzite and the plutonic rock at Wild Yankee Creek is gradational over about $20 \mathrm{~cm}$. In the quartzite the amount of secondary feldspar increases toward the contact, and the quartzite grades to a medium-grained quartz-feldspar rock that contains some blue-green hornblende and a few grains of epidote, magnetite, muscovite, biotite, and sphene.

\section{LOVEJOY BASALT}

Two small areas on a ridge top near Las Plumas substation are capped by an erosional remnant of basalt that is mineralogically similar to the Tertiary Lovejoy Basalt farther east (Hietanen, 1972, 1973a). This basalt is a black fine-grained rock with numerous phenocrysts of plagioclase and augite. Thin sections show three generations of plagioclase $\left(\mathrm{An}_{60}\right)$ 


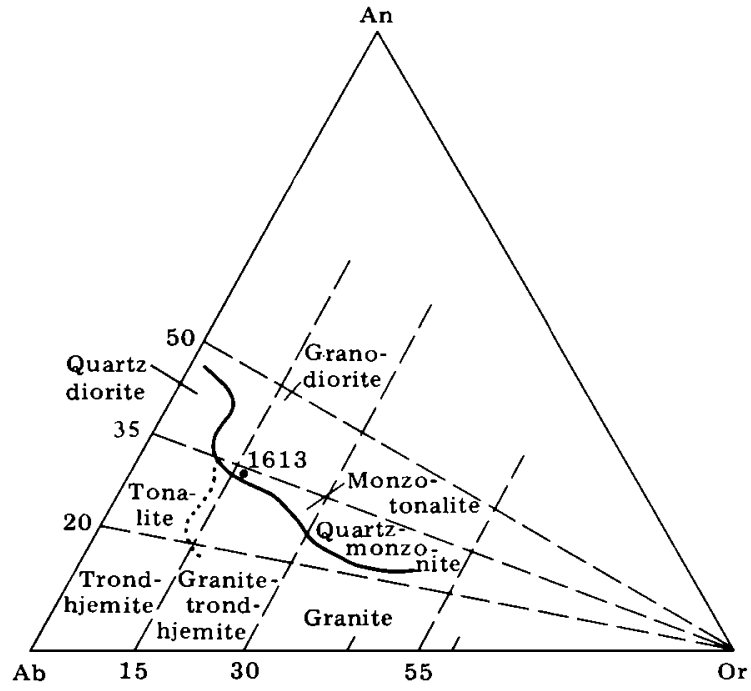

Figure 10.-Ternary Or-Ab-An diagram showing normative feldspar content in the monzotonalite of the Merrimac pluton (loc. 1613) and trend lines for neighboring plutons from Hietanen (1973a, 1976). Solid line, quartz dioritequartz monzonite differentiation series; dotted line, trondhjemitic differentiates.

phenocrysts. The largest phenocrysts are 3-4 mm long and scattered. The medium size (1 mm long) phenocrysts are clustered with augite phenocrysts of the same size. Between these, small $(0.2 \mathrm{~mm}$ long) plagioclase laths are embedded in a fine-grained groundmass that consists of tiny crystals of plagioclase, augite, magnetite, and interstitial glass dusted by disseminated magnetite.

\section{CONCLUSIONS}

The study area yields important new information on the geologic events in the northwestern Sierra Nevada during Paleozoic and Mesozoic time. Only two periods of deformation and metamorphism (one preplutonic, another caused by the emplacement of plutons) could be clearly recognized in the Pulga and Bucks Lake quadrangles (Hietanen, 1973a) and in the area around the Middle and South Forks of the Feather River (Hietanen, 1976) because of the absence of Mesozoic formations that could have provided a necessary time marker in the sequence of events. However, in the Berry Creek quadrangle, the Bloomer Hill Formation provides such a marker. Comparison of the structures and textures of this Mesozoic formation with those of the Paleozoic Horseshoe Bend Formation shows that the Paleozoic rocks were deformed and recrystallized before the Mesozoic volcanic rocks erupted.

The Mesozoic metavolcanic rocks range in compo- sition from augite basalt and andesite through dacite to sodarhyolite and are chemically similar to the Devonian(?) Franklin Canyon Formation farther east (Hietanen, 1973a, 1975). Both of these andesitic suites are poor in potassium which is characteristic of magmas formed during early stages of evolution of modern island arcs (Jakes and Gill, 1970; Jakes and White, 1972). The similarity in chemical composition suggests that subduction similar to that which may have produced a potassium-poor andesitic suite (Franklin Canyon Formation) in Devonian(?) time was active in Jurassic time. A new Benioff zone evolved west of the Paleozoic zone (Hietanen, 1973b, 1975). Similar seaward steppings of the Benioff zone have been suggested by Ernst (1973) for the Coast Ranges and by Burchfiel and Davis (1975) for the Klamath Mountains.

All metavolcanic and metasedimentary rocks were folded together and recrystallized to the greenschist facies during the Nevadan orogeny (Jurassic) that followed the Jurassic volcanism. Plutonism started at the end of this orogeny. The altered gabbro west of Bald Rock pluton and the altered trondhjemite at Big Bend are representatives of the earliest group and are shown as Jurassic on the geologic map (pl. 1). The age of the Merrimac pluton is 130 m.y. according to Grommé, Merrill, and Verhoogen (1967), thus it is Early Cretaceous.

A third period of metamorphism, which was caused by the intrusion of large quantities of plutonic magmas, resulted in contact aureoles 2-3 km wide. Mineral assemblages such as stauroliteandalusite-biotite-quartz near the northwest contact of the Merrimac pluton and cordierite instead of staurolite in the innermost part of the contact zone (Hietanen, 1973a) indicate that the contact metamorphism was at temperatures considerably higher than those that prevailed during the regional metamorphism to the greenschist facies. Temperatures of $550^{\circ}-600^{\circ} \mathrm{C}$ and pressures around $4 \mathrm{~kb}$ were estimated for the contact zone of the Merrimac pluton in the Pulga quadrangle (Hietanen, 1973a). Only a narrow zone (less than $1 \mathrm{~km}$ wide) was heated to this higher temperature.

The emplacement of the plutons probably followed soon after the regional deformation because the wallrocks were still plastic enough to be shouldered aside. A strong foliation was developed parallel to the contact in a zone, $1-2 \mathrm{~km}$ wide, next to the plutons. Lineation in this zone parallels the linear structure of the nearby plutonic rock. New minerals, horn- 
blende and biotite, grew parallel to these new structures that were formed as a result of forcible intrusion of magmas. The contact rocks are not hornfelses but products of deepseated contact metamorphism with the appearance of rocks that have been dynamothermally metamorphosed. In some places, the effect of the elevated temperature can be observed in a wider zone than the newly formed structures. In this outer contact aureole primary volcanic structures are preserved in some Mesozoic rocks, which at moderately low temperatures attained a coarser grain size than the rocks farther from the pluton. Newly crystallized mineral assemblages are those typical of the upper greenschist facies.

\section{REFERENCES}

Burchfiel, B. C., and Davis, G. A., 1975, Nature and controls of Cordilleran orogenesis, Western United States: Extensions of an earlier synthesis: Am. Jour. Sci., v. 275-A, p. 363-396.

Burnett, J. L., and Jennings, C. W., 1962, Geologic map of California, Chico sheet: California Div. Mines and Geology, scale $1: 250,000$.

Clark, L. D., 1964, Stratigraphy and structure of part of the western Sierra Nevada metamorphic belt, California: U.S. Geol. Survey Prof. Paper 410, 70 p.

Compton, R. R., 1955, Trondhjemite batholith near Bidwell Bar, California: Geol. Soc. America Bull., v. 66, no. 1, p. 9-44.

Creely, R. S., 1965, Geology of the Oroville quadrangle, California: California Div. Mines and Geology Bull. 184, p. 1-86.

Ernst, W. G., 1973, Blueschist metamorphism and P-T regimes in active subduction zones: Tectonophysics, v. 17, p. 255-272.

Gromme, C. S., Merrill, R. T., and Verhoogen, J., 1967, Paleomagnetism of Jurassic and Cretaceous plutonic rocks in the Sierra Nevada, California, and its significance for polar wandering and continental drift: Jour. Geophys. Research, v. 72 , no. 22 , p. $5661-5684$.

Hietanen, Anna, 1951, Metamorphic and igneous rocks of the Merrimac area, Plumas National Forest, California: Geol. Soc.
America Bull., v. 62 , no. 6 , p. $565-608$.

1961, A proposal for clarifying the use of plutonic calcalkalic rock names, in Short papers in the geologic and hydrologic sciences: U.S. Geol. Survey Prof. Paper 424-D, p. D340-D343. 1967, On the facies series in various types of metamorphism: Jour. Geology, v. 75, no. 2, p. 187-214.

1972, Tertiary basalts in the Feather River area, California, in Geological Survey research 1972: U.S. Geol. Survey Prof. Paper 800-B, p. B85-B94.

1973a, Geology of the Pulga and Bucks Lake quadrangles, Butte and Plumas Counties, California: U.S. Geol. Survey Prof. Paper 731, 66 p.

$1973 \mathrm{~b}$, Origin of andesitic and granitic magmas in the northern Sierra Nevada, California: Geol. Soc. America Bull., v. 84, no. 6 , p. 2111-2118.

1974, Composition of coexisting amphiboles, epidote minerals, chlorite, and plagioclase in metamorphic rocks, northern Sierra Nevada, California: Am. Mineralogist, v. 59, p. 22-40. 1975 , Generation of potassium-poor magmas in the northern Sierra Nevada and the Svecofennian of Finland: U.S. Geol. Survey Jour. Research, v. 3, no. 6, p. 631-645.

1976, Metamorphism and plutonism around the Middle and South Forks of the Feather River, California: U.S. Geol. Survey Prof. Paper 920, 30 p.

Irwin, W. P., 1966, Geology of the Klamath Mountains province, in Bailey, E. H., ed., Geology of northern California: California Div. Mines and Geology Bull. 190, p. 19-38.

-1972, Terranes of the western Paleozoic and Triassic belt in the southern Klamath Mountains, California, in Geological Survey research 1972: U.S. Geol. Survey Prof. Paper 800-C, p. C103-C111.

Jakes, P., and Gill, J., 1970, Rare earth elements and the island arc tholeiitic series: Earth and Planetary Sci. Letters, v. 9, p. 17-28.

Jakes, P., and White, A. J. R., 1972, Major and trace element abundances in volcanic rocks of orogenic areas: Geol. Soc. America Bull., v. 83, no. 1, p. 29-40.

McMath, V. E., 1966, Geology of the Taylorsville area, northern Sierra Nevada, in Bailey, E. H., ed., Geology of northern California: California Div. Mines and Geology Bull. 190, p. $173-183$.

Turner, H. W., 1898, Bidwell Bar, California: U.S. Geol. Survey Geol. Atlas, Folio 43. 

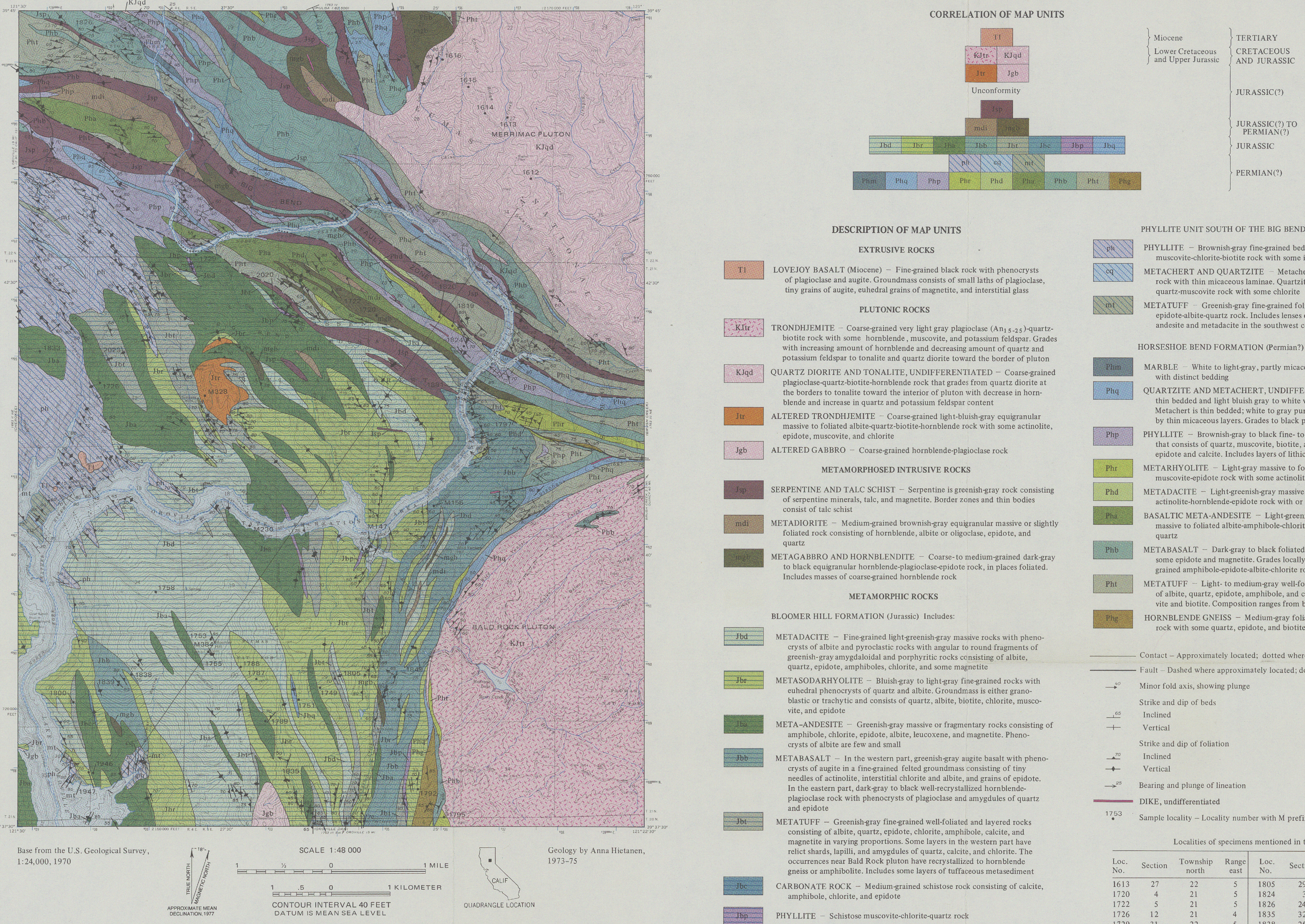

DESCRIPTION OF MAP UNITS

EXTRUSIVE ROCKS

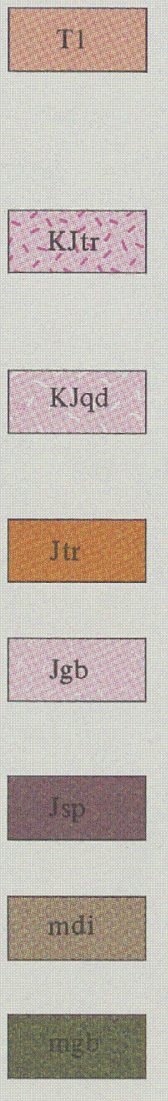

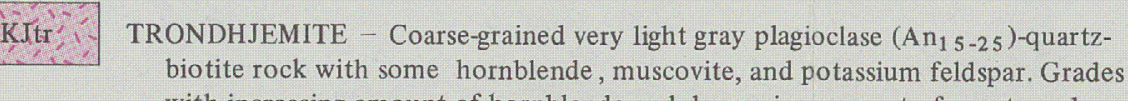
with increasing amount of hornblende and decreasing amount of quart and
potassium feldspar to tonalite and quartz diorite toward the border of pluton

KJad $\quad$ QUARTZ DIORITE AND TONALITE, UNDIFFERENTIATED - Coarse-grained

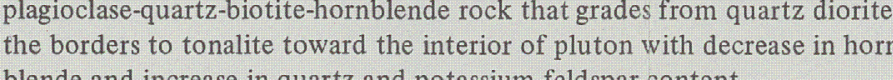
ALTERED TRONDHIJMITE - Coarsegrained light-blushs-grara equigranular
massive to foliated albite-quartz-biotite-hornblende rock with some actinolite,

Igb ALTERED GABBRO - Coarse-grained hornblende-plagioclase rock METAMORPHOSED INTRUSIVE ROCKS

of serpentine minerals, salc, and - Serpentine is greenitite. Border zoray rocks and consisting

METADDORITE - Medium-grained brownish-ray equigranular massive or slightly
foliated rock consistingn of hornblende, albite or oligoclasse, epidote, and

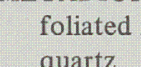

METAGABBRO AND HORNBLENDITE - Caarse-to medium-grained dark-gray
to black equigranular hornblende-plagioclase-epidote rock, in places follated.
Includes masses of coarsegrained hornblende rock Includes masses of coarsegrained hornblende ro
METAMORPHIC ROCKS

BLOOMER HILL FORMATION (IIRST) LeId

$5 \mathrm{sod}$

EETADACITE - Fine-grained lightgreenishrgray massive rocks with pheno-
crysts of albite and pyroclastic rocks with angulart to round framents of

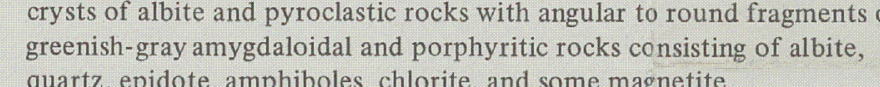

quartz, epidote, amphiboles, chlorite, and some magnetite
WETASODARHYOLTTE - Bluish gray to light gray finegrained rocks with

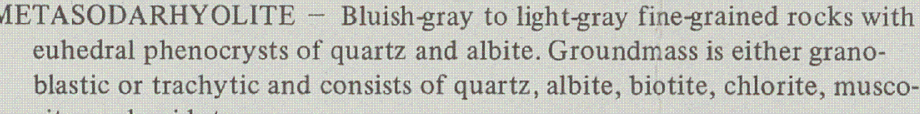

ETA-ANDESITE - Greenish-gray massive or frragmentary rocks consisting of
amphibole, chlorite, epidote, albitite, leucoxene, and magnetite. Pheno-

crysts of albite are tew and small
WETABASALT In In the western part, greenish gray augite basalt with hheno.
crysts of augite in a fine-grained felted groundmass consisting of tiny

sob

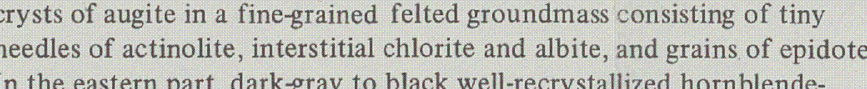
plagioclase rock with phenocrysts of plagioclase and amys dues of quretr plagioclase
and epidote
METTTUFF - G

METATUFF - Greenish gray fine-grained well-foliated and layered rocks
consisting of albite, quartz, epidote, chlorite, anphibole, calcite, and magnetite in varying proportions Some layers in the western part have occurrences mphiblit. Includes some layers of tuffaceous metasediment
gneiss or amplite ARBONATE ROCK - Medium grained schistose rock consisting of calcite,

UARTZITE -
biotite rock

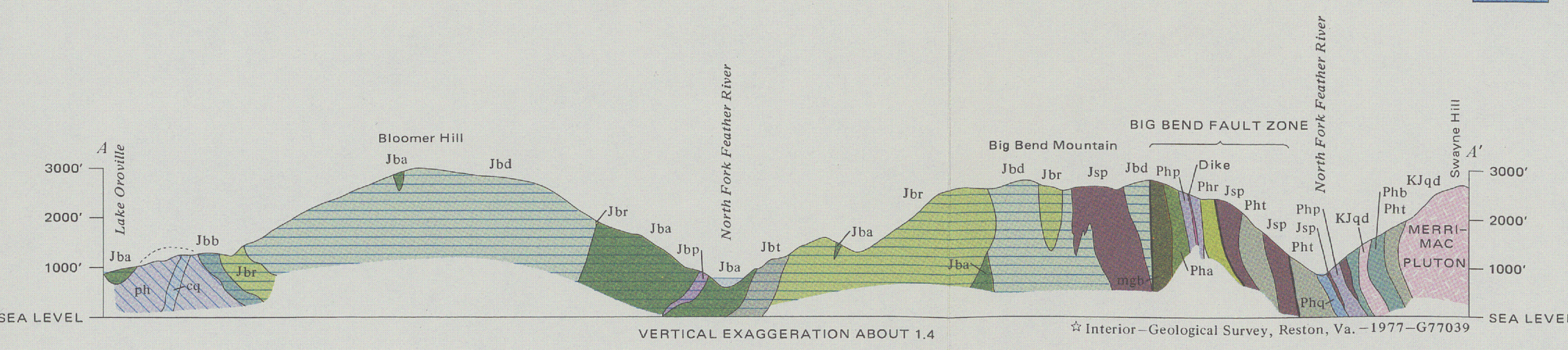

PHYLLITE UNIT SOUTH OF THE BIG BEND FAULT

10.1 PHYLITE - Brownish-gray fine-grained bedded and strongly foliated
muscovite-chlorite-biotite rock with some interbedded lithic metagraywack

Ca 17 METACHERT AND QUARTZITE - Metachert is blue- to light-gray quartz
rock with thin micaceous laminae. Quartzite is a gray granular thin-bedded

mi ovite rock with some chlorite

METATUFF-G Geenish -ray fine-grained foliated chlorite-amphibole-
epidote-albite-quartz rock. Includes lenses of ftrongly deformed meta-

HORSESHOE BEND FORMATION (Permian?) Includes:

MARBLE White to light-gray, partly micaceous calcium carbonate rock

Phy QUARTZITE AND METACHERT, UNDIFFERENIIATED - Quartzite is

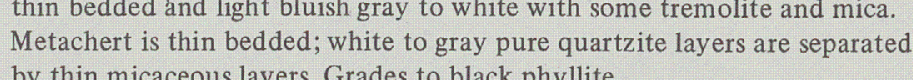

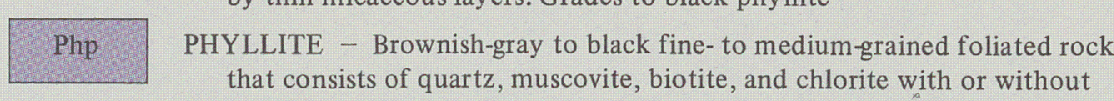
epidote and calcite. Inclustont of lithic metagray wacke

Phr METARHYOLITE - Lightgray massive to foliated quartz-albite-biotite-
muscovite-epidote rock with some ectinolite

Phd METADACITE - Light-greenish-gray massiviv to foliated albite-q

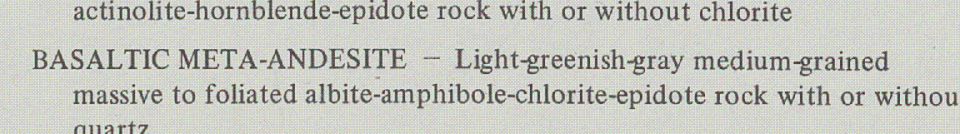
massiviv to foliated albite-amphibole-chlorite-epidote rock with or withou
quartz

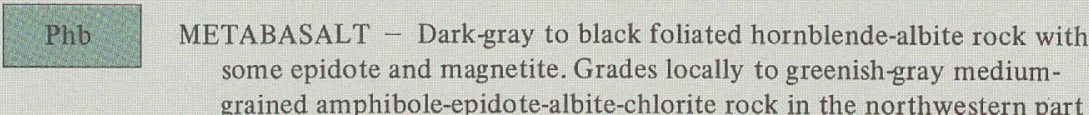

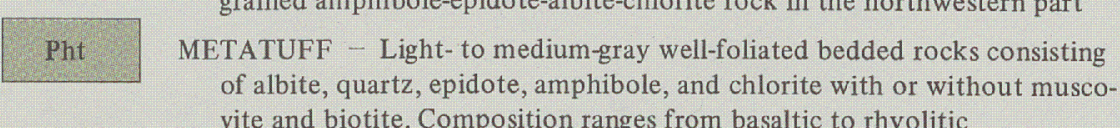

Phy HORNBLENDE GNEISS - Medium-rgay folia
rock with some quartz, epidote, and biotite

\begin{tabular}{|c|c|c|c|c|c|c|c|}
\hline & \multirow{2}{*}{\multicolumn{7}{|c|}{$\begin{array}{l}\text { - Fault - Dashed where approximately located; dotted where concealed } \\
\text { Minor fold axis showing plunre }\end{array}$}} \\
\hline$\rightarrow$ & & & & & & & \\
\hline t & \multicolumn{7}{|c|}{$\begin{array}{l}\text { Strike and dip of beds } \\
\text { Inclined }\end{array}$} \\
\hline$\stackrel{20}{ \pm}$ & \multicolumn{7}{|c|}{$\begin{array}{l}\text { Strike and dip of foliation } \\
\text { Inclined }\end{array}$} \\
\hline & \multicolumn{7}{|c|}{$\begin{array}{l}\text { vertical } \\
\text { Bearing and plunge of lineation }\end{array}$} \\
\hline & \multicolumn{7}{|c|}{ DIKE, undifferentiated } \\
\hline 1753 & \multicolumn{6}{|c|}{ Localities of specimens mentioned in the text } & \\
\hline . & Section & Township & Ragge & Loc. & Section & Township & Range \\
\hline & & & & & & & \\
\hline & $\begin{array}{l}4 \\
5\end{array}$ & ${ }_{21}^{21}$ & $\begin{array}{c}5 \\
5\end{array}$ & 1824 & ${ }_{24}^{3}$ & $\begin{array}{l}21 \\
22\end{array}$ & ${ }_{4}^{3}$ \\
\hline & 12 & 21 & 4 & $\begin{array}{l}1835 \\
1838\end{array}$ & 32 & 21 & 5 \\
\hline & 29 & 21 & & $\begin{array}{l}1839 \\
1839 \\
\end{array}$ & 25 & 21 & 4 \\
\hline & ${ }_{30}^{29}$ & ${ }_{21}^{21}$ & $\begin{array}{l}5 \\
5\end{array}$ & $\begin{array}{l}1849 \\
1881\end{array}$ & $\begin{array}{l}28 \\
10\end{array}$ & $\begin{array}{l}21 \\
21\end{array}$ & ${ }_{5}^{5}$ \\
\hline & 30 & 21 & 5 & $\begin{array}{l}M 147 \\
\text { M156 }\end{array}$ & 21 & ${ }_{21}^{21}$ & 5 \\
\hline & 30 & 21 & 5 & 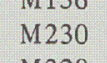 & 18 & 21 & 5 \\
\hline & $\begin{array}{l}33 \\
10\end{array}$ & $\begin{array}{l}21 \\
21\end{array}$ & 5 & & $\begin{array}{c}7 \\
30\end{array}$ & $\begin{array}{l}21 \\
21\end{array}$ & $\begin{array}{c}5 \\
5\end{array}$ \\
\hline & & & & & & & \\
\hline
\end{tabular}


